\title{
STRATEG]GKR Ř́zENIJ
}

Prof. PhDr. František Ochrana, DrSc.

Analytičtí a koncepční pracovníci

rezortu Ministerstva obrany

v zrcadle výzkumného projektu

„Analytici politiky v ústřední státní

správě České republiky: praktiky, profesní hodnoty a identita"

Vojenské rozhledy, 2014, roč. 23 (55), č. 1, s. 50-80, ISSN 1210-3292

\section{Analytical and Conception Personnel of Defence Department in the Mirror of Research Project "Political Analysts of Central State Administration of the Czech Republic: Practices, Professional Values, and Identity"}

\section{Abstrakt:}

Příspěvek se pokouši o analýzu zaměstnanců ústředni státni správy, kteři vykonávaji analytické, koncepční, plánovaci a strategické činnosti. K poznání role těchto pracovníků byl proveden výzkum realizovaný na jedenácti ministerstvech v roce 2013. Výzkumu se z vlastního rozhodnutí nezúčastnila pouze tři ministerstva (Ministerstvo vnitra, Ministerstvo pro místní rozvoj a Ministerstvo zemědělství). Výsledky výzkumu podávaji informace o tom, jak zkoumaná skupina pracovniků hodnotí rüzné faktory ovlivňujicich výkon jejich analytické a koncepčni činnosti. Jsou prováděna porovnávání zjištěného stavu na Ministerstvu obrany s celkovým stavem na ministerstvech České republiky. V závěru článku jsou formulovány určité náměty a doporučení pro zlepšeni existujicího stavu.

\section{Abstract:}

This article tries to analyse the employees of central state administration, who are involved in analytical, conception, planning and strategy activities. We organized a research at eleven ministries in 2013, to familiarize themselves with their roles. Only three ministries refused to take part in this research (home office, regional development ministry and agriculture ministry). The results reached describe how examined groups evaluated various factors influencing their analytic and conception performances. The identified state at the Defence Ministry is compared with overall situations at other ministries of the Czech Republic. At the end of this article the author expresses certain suggestions and recommendations how to improve current state of affairs. 


\section{Klíčová slova:}

Personál, státní správa, Ministerstvo obrany, výzkum, respondenti, věková struktura, genderová nevyváženost, nejvyšší dosažené vzdělání, řešení analytických úkolů, faktory ovlivňující činnost analytiků státní správy, politické zájmy, profesní hodnoty analytiků státní správy.

\section{Key words:}

Personnel, state administration, defence ministry, research, respondents, age group, gender asymmetry, highest level of education achieved, solution of analytical tasks, factors influencing the activities of state administration analysts, political interests, professional qualities of state administration analysts.

\section{Úvod}

Tento článek se zabývá zkoumáním tzv. analytiků ústřední státní správy. Tímto termínem se označuje ta skupina odborných pracovníků ministerstev, kteří mají ve své pracovní náplni stanoveno vykonávat vysoce kvalifikovanou analytickou, koncepční, strategickou a prognostickou činnost. V zahraničí podobný problém zkoumají např́klad Bakvis (1997), Howlett (2009), Wellstead a Stedman (2011). V České republice se uvedenému problému věnuje Veselý (2012), který zkoumá roli analytických a koncepčních pracovníků ústřední státní správy. V rezortu Ministerstva obrany existují práce, které se zabývají problematikou personálu z pohledu profesionalizace ozbrojených sil (viz Pernica, 2007), či různé interní studie odborníků personalistiky rezortu Ministerstva obrany (Černoch a Královec, Karaffa), které se např́klad staly i jedním ze zdrojů při tvorbě Bílé knihy o obrané.

Článek se opírá o vlastní empirické zkoumání realizované v rámci výzkumného projektu Grantové agentury České republiky P 404/12/0725 „Analytici politiky v ústřední státní správě České republiky: praktiky, profesní hodnoty a identita“. Výzkumu se zúčastnila všechna ministerstva vyjma Ministerstva vnitra, Ministerstva pro místní rozvoj a Ministerstva zemědělství, která se empirického šetření z vlastního rozhodnutí nezúčastnila. Výzkum probíhal v období duben - červen 2013. Ke zdárnosti výzkumu přispěl značnou měrou PhDr. Libor Konvička z agentury STEM/MARK. Bohužel se dokončení výzkumu nedožil. Tento článek je připsán jeho památce.

Článek si klade za cíl na základě vlastního empirického zkoumání přispět k poznání role analytických a koncepčních pracovníků ústřední státní správy obecně a Ministerstva obrany zvlášt' a pokusit se formulovat určitá doporučení ke zlepšení existujícího stavu.

Z hlediska logiky zkoumání má článek dvě metodologické roviny, a to rovinu pozitivní analýzy a rovinu normativní analýzy (viz Ochrana, 2013). Pozitivní (popisná analýza) je charakteristická pro tu část článku, kde jsou jednotlivé tabulky s příslušnými komentáři. Autor tak poskytuje nezainteresovanou (nehodnocenou) informaci těm, kteří se chtějí sami zabývat analýzou daných informací. Normativní část je obsažena v závěru článku. Tato část se pokouší o hodnocení daného stavu. Tak jako každá normativní analýza je i tato hodnocením daného stavu z normativních (hodnotových) 
pozic a vlastních zkušeností autora článku. Protože kritický čtenář má k dispozici popisné informace z výzkumu a př́padně disponuje dalšími informacemi a vlastními zkušenostmi $\mathrm{k}$ dané problematice, může si sám učinit př́ípadné korekce k závěrům obsaženým v tomto článku.

\section{Charakteristika výzkumu}

Předmětem zkoumání byl profil zmíněné skupiny vysoce kvalifikovaných pracovníků ministerstev, kteří se zabývají analytickou, koncepční, strategickou a prognostickou činností. Do výzkumu tedy nebyli zahrnuti ti zaměstnanci ministerstev, kteří se věnují takovým činnostem, jako jsou údržba, chod sekretariátu, účetnictví, „,běžná administrativa“, apod. Základem pro výběr respondentů byl seznam potenciálních respondentů, který zpracovala jednotlivá ministerstva. Respondenti byli vybíráni náhodně. Sérií náhodných výběrů byly osloveny všechny (nebo téměř všechny) jednotky zahrnuté do databáze jednotlivých ministerstev. Náhodný výběr se tak stal prakticky vyčerpávajícím výběrem.

\subsection{Formy dotazování}

Dotazování proběhlo následujícími formami: u osmi ministerstev formou osobního dotazování (F2F - face-to-face), a to formou dotazníku s přesně předepsanými otázkami, a to do papírových dotazníků (tzv. CAPI) nebo s využitím notebooku (tzv. PAPI). U dvou ministerstev bylo provedeno dotazování vyplňováním on line dotazníku (tzv. CAWI) bez účasti tazatele jako tzv. „nouzová“ forma řešení pro př́pad, že nebylo možné z důvodu získání odpovědí postupovat formou F2F. V jednom př́padě byla použita kombinace obou metod (F2F a CAWI). Celkem bylo dotázáno 1351 respondentů. Většina dotazníků byla vyplněna metodou PAPI (992 dotazníků), metodou CAPI bylo vyplněno 124 dotazníků a 235 dotazníků metodou CAWI.

\subsection{Interpretace výsledků}

Jednotlivá jiná ministerstva nejsou při konkrétní interpretaci výsledků uváděna z důvodů garantované anonymity výzkumu. Navíc by ani nebylo vhodné vytvářet nějaké veřejné ,„pomyslné žebříčky“ o umístění jednotlivých ministerstev ve srovnání s jinými ministerstvy. Každé ministerstvo je totiž svým způsobem specifické, jak vyplývá ze zákona č. 2/1969 Sb., o zřízení ministerstev a jiných ústředních orgánů státní správy, ve znění pozdějších předpisů. Má daným zákonem stanovené své jedinečné působnosti, které jsou obtížně př́imo srovnatelné s jinými ministerstvy. Proto je potřebné případná srovnání brát jako relativní a podmíněné výpovědi ovlivněné specifikou každého ministerstva. Srovnání Ministerstva obrany bude proto učiněno s průměrem za všechna ministerstva. V doporučujícím závěru jsou některá ministerstva zmíněna a to tam, kde se jedná o společné problémy státní správy, jejichž řešením by se měla zabývat vláda, ministři, př́ípadně zákonodárci. 


\section{Charakteristika výzkumného vzorku z pohledu počtu respondentů, pohlaví, věkové struktury a dosaženého vzdělání}

Při výzkumu bylo osloveno 226 pracovníků Ministerstva obrany, což představuje $17 \%$ z celkového počtu oslovených respondentů. Při zkoumání skupiny pracovníků Ministerstva obrany nebylo především z důvodu transakčních nákladů rozlišováno, zda se jedná o vojáky z povolání či o civilní zaměstnance. Průměrný počet oslovených respondentů činil 123 osob za všechna ministerstva. Návratnost dotazníků v př́padě Ministerstva obrany činila 100 dotazníků (tedy 44 \%), což přesně odpovídá průměru počtu dotazovaných za všechna ministerstva (podle pohlaví v průměru 50 mužů a 50 žen). V př́ípadě Ministerstva obrany odpovědělo 84 mužů a 16 žen. Jak je z uvedených údajů zřejmé, na Ministerstvu obrany dominují muži, což je vcelku přirozené. K uvedenému genderovému složení přispívá i skutečnost, že zdroje analytických pracovníků v oblasti obrany plynou do rezortu Ministerstva obrany pravděpodobně z nemalé části z ,,vnitřních zdrojư“ (absolventi vojenských škol, bývalí vojáci z povolání), a taktéž k tomu přispívá fakt, že obrana je tradičně pojímána jako „mužské povolání“. Bezprostřední „,bojová vojenská činnost" (myšleno účast v bojových akcích) i nadále zůstane doménou mužů, avšak v průběhu následujících deseti až dvaceti let je možné pravděpodobně očekávat, že pozice tzv. analytiků a koncepčních pracovníků na Ministerstvu obrany budou ve větší míře zaujímat i ženy. Tuto domněnku lze opřít o skutečnost, že na civilních univerzitách a vysokých školách v ČR jsou studovány nově zakládané studijní „,bezpečnostní obory“, které budou i pro rezort Ministerstva obrany produkovat absolventy (a absolventky), kteří se mohou stávat potenciálními zájemci o funkce, jejichž náplní je analytická a koncepční činnost v rezortu Ministerstva obrany.

Následující tab. 1 vypovídá o věkové struktuře. Z tabulky jsou zřejmé dvě informace. První se týká věkového složení zaměstnanců podle jednotlivých věkových rozmezí (18-29 let; 30-44 let; 45-59 let; 60 a více let) a podle mediánu věku, kdy dané číslo odpovídá na otázku ,ppolovina zaměstnanců je mladší než..."

Tab. 1: Věková struktura dotazovaných

\begin{tabular}{|l|c|c|}
\hline \multicolumn{1}{|c|}{ Sledovaný ukazatel } & \multicolumn{2}{c|}{ Zkoumaná složka } \\
\hline Věk (\%) & Ministerstvo obrany & Ministerstva celkem \\
\hline $18-29$ & 5 & 16 \\
\hline $30-44$ & 26 & 40 \\
\hline $45-59$ & 61 & 31 \\
\hline 60 a více & 100 & 13 \\
\hline Celkem \% & 50 & 42 \\
\hline Medián věku & & 400 \\
\hline
\end{tabular}

Pramen: Vlastní výzkum v rámci projektu GAČR P 404/12/0725 „Analytici politiky v ústřední státní správě České republiky: praktiky, profesní hodnoty a Prof. PhDr. František Ochrana, DrSc.

Ministerstvo obrany se poměrně liší věkovým složením analytických pracovníků. Medián věku dosahuje 50 let, který je nad průměrem 42 let mediánu věku ministerstev. To lze pravděpodobně vysvětlit tím, že analytici Ministerstva obrany vykonávají 
natolik specifickou činnost, která si na rozdíl od jiných ministerstev vyžaduje specifické poznatky podepřené relativně delší praxí v oboru vojenské teorie a praxe.

Údaje z tab. 1 také bortí jeden z mýtů o rezortu Ministerstva obrany, který panuje v laické veřejnosti o ,přestárlosti“ pracovníků v rezortu Ministerstva obrany. Jak ukazují výsledky zkoumání, zcela jistě to neplatí pro zkoumanou kategorii analytických a koncepčních pracovníků v kategorii 60 a více let, která je zastoupena pouze osmi procenty dotazovaných pracovníků. Teprve věková kategorie 45-59 let v př́padě Ministerstva obrany silně dominuje s 61 \% z celkového počtu dotazovaných. To lze pravděpodobně vysvětlit tím, že analytická a koncepční činnost v rezortu Ministerstva obrany vyžaduje v mnohém specifické znalosti opřené (i) o vojenskou vědu a o poznatky z vojenské praxe. Proto také tyto analytické a koncepční pozice zaujímají bývalí vojáci z povolání, kteří „vysvlékají uniformu“ a odcházejí do zálohy. Protože se tak děje po určité době odsloužených let, přirozeně to má dopady na věkové složení pracovníků rezortu Ministerstva obrany ve zmiňované kategorii 45-59 let.

Svým způsobem je to přirozeně vysvětlitelné. Specifika některých analytických činností na Ministerstvu obrany vyžaduje zkušenosti z předchozí (vojenské) praxe. A zkušenosti lze získat jen praxí. Přesto však lze i v této oblasti hledat inovace, jak blíže ukazuje závěr tohoto článku. Následující tabulka 2 vypovídá o nejvyšším dosaženém vzdělání.

Tab. 2: Nejvyšší dosažené vzdělání dotazovaných zaměstnanců

\begin{tabular}{|l|c|c|}
\hline \multicolumn{1}{|c|}{ Sledovaný ukazatel } & \multicolumn{2}{c|}{ Zkoumaná složka } \\
\hline Vzdělání & Ministerstvo obrany & Ministerstva celkem \\
\hline Bez maturity & 0 & 0 \\
\hline Středoškolské s maturitou & 0 & 2 \\
\hline Vyšší odborné & 0 & 5 \\
\hline VŠ-bakalářské & 81 & 71 \\
\hline VŠ - magisterské & 15 & 13 \\
\hline VŠ-doktorské & 0 & \\
\hline Poznámka & $\begin{array}{l}\text { Zbývající jedno procento } \\
\text { je rovnoměrně rozloženo } \\
\text { v jednotlivých položkách. }\end{array}$ \\
\hline
\end{tabular}

Pramen: Vlastní výzkum v rámci projektu GAČR P 404/12/0725 „Analytici politiky v ústřední státní správě České republiky: praktiky, profesní hodnoty a identita“.

Jak ukazuje tabulka, zkoumaný vzorek Ministerstva obrany dosahoval s 96 \% nejvyššího procentního počtu vysokoškolsky (magistři a doktorské studium) vzdělaných pracovníků. Ministerstvo obrany se v tomto ukazateli zřetelně liší ve srovnání s průměrem ministerstev, který činí 84 \% podíl magisterského a doktorsky vzdělaného analytického personálu. Výzkum rovněž ukazuje, že některá ministerstva mají na rozdíl od Ministerstva obrany relativně vysoký počet zaměstnanců se středoškolským vzděláním s maturitou. Jedním z možných vysvětlení je, že zřejmě existují ministerstva, kde dostačující kvalifikací na výkon některých analytických prací může být i středoškolské vzdělání s maturitou. To je v př́padě rezortu Ministerstva obrany spíše výjimkou, kde tento stupeň dosaženého vzdělání uvádí pouhá $3 \%$ dotazovaných pracovníků. Pokud platí předpoklad, že pro výkon analytické a koncepční činnosti v rezortu Ministerstva obrany jsou potřebné (i) znalosti 
vojenské vědy a vojenské praxe, pak takové znalosti jsou získávány na vojenských vysokých školách a Univerzitě obrany. Také to přirozeně zvyšuje podíl vysokoškolsky vzdělaných analytiků. Dalším důvodem může být, že část pracovníků jiných ministerstev s relativně vysokým počtem středoškoláků s maturitou vykonává ve vyšší míře méně složité (spíše rutinní) úkoly, jak ukazuje další analýza (viz tab. 10, 11, 12).

\section{Charakteristika podle dosavadních pracovních zkušeností}

Za ukazatele dosavadních pracovních zkušeností vezmeme tyto indikátory: předchozí pracovní zkušenosti, počet odpracovaných let v současné funkci, počet odpracovaných let na ministerstvu a počet let odpracovaných ve veřejné správě. Informace o předchozích pracovních zkušenostech podává následující tabulka.

Tab. 3: Pracovní zkušenosti z jiných sektorů

\begin{tabular}{|l|c|c|}
\hline \multicolumn{1}{|c|}{ Sledovaný ukazatel } & \multicolumn{2}{c|}{ Zkoumaná složka } \\
\hline Sektor & Ministerstvo obrany & Ministerstva celkem \\
\hline Veřejný & 33 & 40 \\
\hline Nestátní neziskový & 3 & 38 \\
\hline Komerční & 17 & 8 \\
\hline Akademická sféra & 4 & 13 \\
\hline Bez předchozích zkušeností & 18 & 22 \\
\hline Jiná oblast & 46 & 7 \\
\hline
\end{tabular}

Pramen: Vlastní výzkum v rámci projektu GAČR P 404/12/0725 „Analytici politiky v ústř̌ední státní správě České republiky: praktiky, profesní hodnoty a identita“.

Jak je z tab. 3 zřejmé, u ministerstev převažují zkušenosti z veřejného a komerčního sektoru, kdy tuto zkušenost má v průměru kolem čtyřiceti procent zaměstnanců. Toto zjištění není př́liš překvapivé. Lze se domnívat, že pracovníci, kteří zahajují kariéru ve veřejném sektoru, v tomto sektoru také zůstávají, a pravděpodobně z něho méně odcházejí do komerčního sektoru, což však pravděpodobně neplatí naopak. Pracovníci komerčního sektoru tedy více „migrují“ do veřejného sektoru nežli pracovníci veřejného sektoru do komerčního sektoru.

Z údajů lze také vypozorovat, že zkoumaná skupina pracovníků ministerstev nemá př́liš časté zkušenosti z neziskového sektoru a akademické sféry. To je dáno pravděpodobně tím, že pracovníky akademické sféry, kde vládne relativně volný časový režim, neláká služba ve státní správě s relativně striktně danými pravidly. To platí i pro rezort Ministerstva obrany, kdy pouze čtyři procenta analytiků pochází z akademické sféry. Motivy vstupu těchto bývalých akademiků na Ministerstvo obrany mohou být různé. Za pravděpodobné můžeme považovat reorganizaci na předchozím akademickém pracovišti (ztráta místa), touha po kariéře ministerského pracovníka a s tím spojená relativní prestiž (viz v další části citované studie zjištěný poměrně vysoký pocit hrdosti pracovníků Ministerstva obrany na svoje postavení), rodinné důvody. 
Pokud se týká pracovníků neziskových organizací, pak tito pravděpodobně mají ,jiný hodnotový svět" daný posláním a specifikou neziskových organizací, a proto je neláká vyměnit svět neziskových organizací za státní správu s relativně striktně danými pravidly. Nepřekvapuje proto, že v rezortu Ministerstva obrany mají s touto činností zkušenosti pouhá tři procenta respondentů.

Jak je zřejmé, v rezortu Ministerstva obrany silně dominuje pracovní zkušenost nazvaná ,jiná oblast“. Toto zjištění podporuje již zmiňovanou hypotézu o analytických a koncepčních pracovnících rezortu, kteří pro svůj výkon potřebují (i) vojenské poznatky a vojenskou praxi. Tím lze také (v současném kontextu zmiňované hypotézy o „striktnosti““ pravidel státní správy) vysvětlit, proč do rezortu Ministerstva obrany vstupují pouze tři procenta pracovníků z nestátního neziskového sektoru.

Přibližně třetina dotázaných pracovníků rezortu Ministerstva obrany má zkušenosti z veřejného sektoru. Lze se domnívat, že podstatnou část tvoří „migranti“, kteří přicházejí z jiných ministerstev, kde předtím ale vykonávali činnosti spojené s bezpečností státu. Pro prověření této hypotézy by však byly potřebné dodatečné informace, které nebyly předmětem výzkumu.

Téměř pětina respondentů nemá žádné předchozí zkušenosti. To jsou absolventi vysokých (vojenských) škol, kteří začínají svoji kariéru v rezortu Ministerstva obrany. Informace o indikátoru ukazatele počtu odpracovaných let ve stávající funkci podává tab. 4.

Tab. 4: Počet let odpracovaných ve stávající funkci

\begin{tabular}{|l|c|c|}
\hline \multicolumn{1}{|c|}{ Sledovaný ukazatel } & \multicolumn{2}{c|}{ Zkoumaná složka } \\
\hline $\begin{array}{l}\text { Počet odpracovaných let ve stávající } \\
\text { funkci }\end{array}$ & Ministerstvo obrany & Ministerstva celkem \\
\hline 0-3 roky & 39 & 44 \\
\hline 3-5 let & 28 & 18 \\
\hline 6-10 let & 21 & 13 \\
\hline 11 a více let & 11 & \\
\hline Poznámka & $\begin{array}{l}\text { Zbývající jedno procento } \\
\text { je rovnoměrně rozloženo } \\
\text { v jednotlivých položkách. }\end{array}$ \\
\hline
\end{tabular}

Pramen: Vlastní výzkum v rámci projektu GAČR P 404/12/0725 „Analytici politiky v ústř̌ední státní správě České republiky: praktiky, profesní hodnoty a identita“.

Také v tomto případě výzkum vyvrací další z mýtů o zaměstnancích státní správy, že tito se „drži““ dlouhodobě ve svých funkcích. Téměř polovina respondentů $(44 \%)$ ve své funkci začíná, resp. v ní pracuje v délce do tř́ let. Čtvrtina dotazovaných pracuje ve své funkci 3-5 let. Pokud se týká rezortu Ministerstva obrany, pak téměř šedesát procent dotázaných pracuje ve své funkci do pěti let, což je pod celkovým průměrem ministerstev, který činí 69\%. Také z uvedených údajů nelze činit žádná striktní srovnávání o „fluktuaci“ zaměstnanců, jak by se mohlo na první pohled zdát. Jde spíše o pohyby, které jsou dány profesní dráhou (resp. kariérním řádem). K prověření této domněnky by bylo potřebné mít dodatečné údaje o tom, jak dlouho každý jednotlivý pracovník pracuje na ministerstvu a jakou funkci (funkce) předtím zastával. Určitou odpověd' na uvedenou otázku může podat indikátor počet odpracovaných let na ministerstvu. Informace o něm dává tab. 5 . 
Tab. 5: Počet let odpracovaných na ministerstvu

\begin{tabular}{|l|c|c|}
\hline \multicolumn{1}{|c|}{ Sledovaný ukazatel } & \multicolumn{2}{c|}{ Zkoumaná složka } \\
\hline $\begin{array}{l}\text { Počet odpracovaných let } \\
\text { na ministerstvu }\end{array}$ & Ministerstvo obrany & Ministerstva celkem \\
\hline 0-3 roky & 12 & 29 \\
\hline 3-5 let & 14 & 22 \\
\hline 6-10 let & 22 & 19 \\
\hline $11-20$ let & 30 & 21 \\
\hline 21 a více let & 22 & 9 \\
\hline
\end{tabular}

Pramen: Vlastní výzkum v rámci projektu GAČR P 404/12/0725 „Analytici politiky v ústřední státní správě České republiky: praktiky, profesní hodnoty a identita“".

Z údajů je zřejmé, že pro ministerstva jako celek neplatí jednoduchý vztah, že počet let odpracovaných ve stávající funkci se rovná počtu odpracovaných let na ministerstvu. Přes sedmdesát procent respondentů pracuje na svém ministerstvu déle než tři roky, přibližně polovina déle nežli pět let.

Jak je z tab. 5 zřejmé, na Ministerstvu obrany pracuje s jasnou převahou nejvíce zaměstnanců s počtem odpracovaných let nad dvacet jedna let a přes padesát procent z nich pracuje na Ministerstvu obrany více než jedenáct let. To posiluje domněnku o specifice analytických a koncepčních pracovníků rezortu Ministerstva obrany, kteří k výkonu své funkce potřebují vedle vzdělanostní složky i potřebnou vojenskou praxi. Tuto hypotézu posilují i následující údaje v tabulce 6 .

Tab. 6: Počet let odpracovaných ve veřejné správě

\begin{tabular}{|l|c|c|}
\hline \multicolumn{1}{|c|}{ Sledovaný ukazatel } & \multicolumn{2}{c|}{ Zkoumaná složka } \\
\hline $\begin{array}{l}\text { Počet odpracovaných let } \\
\text { na ministerstvu }\end{array}$ & Ministerstvo obrany & Ministerstva celkem \\
\hline 0-4 roky & 10 & 31 \\
\hline 5-10 let & 15 & 24 \\
\hline $11-20$ let & 22 & 24 \\
\hline 21 a více let & 53 & 21 \\
\hline
\end{tabular}

Pramen: Vlastní výzkum v rámci projektu GAČR P 404/12/0725 „Analytici politiky v ústřední státní správě České republiky: praktiky, profesní hodnoty a identita“.

Jak je z údajů zřejmé, cca $70 \%$ zkoumaného vzorku zaměstnanců pracuje ve veřejné správě více jak pět let, přičemž cca pětina dotazovaných pracuje ve veřejné správě více než 21 let. Pokud se týká Ministerstva obrany, toto se liší tím, že více jak $90 \%$ zaměstnanců pracovalo ve veřejné správě více jak pět let, přičemž polovina zaměstnanců pracovala ve veřejné správě více jak 21 let. To může být dáno různými faktory. Jedním z nich jsou již zmiňovaná specifika odborných činností, jež vyžadují vedle specifické vzdělanostní složky i určitou délku vojenské praxe, kterou je možné získat jen delším působením v daném rezortu. Dalším faktorem může být i spokojenost s prací, pokud jde o zajímavost práce a možnost povýšení. Podrobnosti ukazuje tab. 7. 


\section{Vnímání své pozice na ministerstvu}

Další otázkou bylo, jak daní pracovníci osobně vnímají svoji pracovní roli. To bylo zjišt'ováno na základě výběru termínu (slova), které podle názoru dotazovaných nejlépe vysvětluje jejich roli na ministerstvu. Výsledky zkoumání ukazuje následující tab. 7.

Tab. 7: Jaké slovo nejlépe vystihuje vaši pozici

\begin{tabular}{|l|c|c|}
\hline \multicolumn{1}{|c|}{ Sledovaný ukazatel } & \multicolumn{2}{c|}{ Zkoumaná složka } \\
\hline Pozice a její procento & Ministerstvo obrany & Ministerstva celkem \\
\hline Úředník & 30 & 43 \\
\hline Manažer & 23 & 15 \\
\hline Právník & 16 & 13 \\
\hline Analytik & 10 & 8 \\
\hline Ekonom & 5 & 5 \\
\hline Jiné & 20 & 15 \\
\hline
\end{tabular}

Pramen: Vlastní výzkum v rámci projektu GAČR P 404/12/0725 „Analytici politiky v ústřední státní správě České republiky: praktiky, profesní hodnoty a identita“.

Jak je z odpovědí zřejmé, největší zastoupení má pozice „úuředník“, kdy se respondenti s rolí úřredníka ztotožňují kolem čtyřiceti až padesáti procent. Ministerstvo obrany se poměrně výrazně liší od jiných ministerstev, kdy tuto roli takto vnímá pouze $30 \%$. To pravděpodobně souvisí se specifikou odborné práce zkoumané skupiny zaměstnanců Ministerstva obrany. Také v př́padě vnímání zastávané role „manažer“ se Ministerstvo obrany liší, kdy více než pětina dotazovaných vnímá svoji roli jako „manažer“, kdežto v průměru všech ministerstev takto tuto svoji roli vnímá $15 \%$ dotázaných. Mírně nad průměrem je vnímání role „právník“a ,analytik“. Pracovníci Ministerstva obrany vnímají svoji roli ,analytika“ nad průměrem osmi procent a jako „ekonoma“ přesně v průměru pěti procent. Pětina pracovníků vnímá svoji roli jako ,jiné“. Jak je zřejmé, Ministerstvo obrany se tímto výrazně liší od jiných ministerstev, což je dáno pravděpodobně tím, že Ministerstvo obrany má řadu vysoce specifických činností souvisejících se specifikou vnější bezpečnosti státu.

\section{Oblast pracovních úkolů, jejich složitost a naléhavost}

Dalším zkoumaným problémem bylo zkoumání, kolik procent respondentů se jak často v průměru věnuje řešení problémů, které mají jediné, jasné a relativně jednoduché řešení. Výsledky zkoumání ukazuje tab. 8.

Jak je z odpovědí zřjejmé, v průměru $43 \%$ dotázaných uvedlo, že problémům, které mají jediné, jasné a relativně jednoduché řešení, se věnují denně. Výzkum nezachycoval povahu a obsah těchto problémů. Lze se však domnívat, že uvedené problémy spíše souvisejí s tzv. operativními úkoly, které je samožrejmě potřebné řešit, avšak tyto odčerpávají kapacity pro výkon koncepční činnosti ministerstev, resp. dané zkoumané 
skupiny pracovníků. Ministerstvo obrany je svými $44 \%$ přibližně na průměru všech ministerstev. Pokud k dané frekvenci připočteme i údaj „několikrát za týden“, pak ministerstva vynakládají v průměru $68 \%$ procent času na výkon problémů, které mají jediné, jasné a relativně jednoduché řešení. To je poměrně nepř́znivé zjištění s ohledem na zkoumanou skupinu respondentů, kteří by se jako ministerští zaměstnanci měli s ohledem na povahu ústředních orgánů státní správy zabývat koncepční a strategickou činností, tedy obrazně řečeno ,spíše budoucností nežli každodenností“.

Tab. 8: Kolik procent respondentů se jak často v průměru věnuje řešení problémů, které mají jediné, jasné a relativně jednoduché řešení

\begin{tabular}{|l|c|c|}
\hline \multicolumn{1}{|c|}{ Sledovaný ukazatel } & \multicolumn{2}{c|}{ Zkoumaná složka } \\
\hline Frekvence a její procento & Ministerstvo obrany & Ministerstva celkem \\
\hline Denně & 44 & 43 \\
\hline Několikrát za týden & 22 & 25 \\
\hline Několikrát za měsíc & 16 & 5 \\
\hline Několikrát za čtvrtletí & 5 & 7 \\
\hline Několikrát za rok & 9 & 3 \\
\hline Nikdy & 4 & $\begin{array}{l}\text { Zbývající jedno procento } \\
\text { je rovnoměrně rozloženo } \\
\text { v jednotlivých položkách. }\end{array}$ \\
\hline Poznámka & & \\
\end{tabular}

Pramen: Vlastní výzkum v rámci projektu GAČR P 404/12/0725 „Analytici politiky v ústřední státní správě České republiky: praktiky, profesní hodnoty a identita“.

Porovnání zjištěných údajů obsažených v tab. 8 je zajímavé srovnávat s tím, kolik procent respondentů se v průměru jak často věnuje řešení problémů, které nemají jediné, jasné a relativně jednoduché řešení. Ty lze pokládat za problémy vyžadující tvořivý př́stup. Výsledky zkoumání ukazuje tab. 9.

Tab. 9: Kolik procent respondentů se jak často v průměru věnuje řešení problémů, které nemají jediné, jasné a relativně jednoduché řešení

\begin{tabular}{|l|c|c|}
\hline \multicolumn{1}{|c|}{ Sledovaný ukazatel } & \multicolumn{2}{c|}{ Zkoumaná složka } \\
\hline Frekvence a její procento & Ministerstvo obrany & Ministerstva celkem \\
\hline Denně & 24 & 25 \\
\hline Několikrát za týden & 31 & 32 \\
\hline Několikrát za měsíc & 28 & 27 \\
\hline Několikrát za čtvrtletí & 11 & 10 \\
\hline Několikrát za rok & 5 & 5 \\
\hline Nikdy & 0 & 1 \\
\hline Poznámka & $\begin{array}{l}\text { Zbývající jedno procento } \\
\text { je rovnoměrně rozloženo } \\
\text { v jednotlivých položkách. }\end{array}$ \\
\hline
\end{tabular}

Pramen: Vlastní výzkum v rámci projektu GAČR P 404/12/0725 „Analytici politiky v ústřední státní správě České republiky: praktiky, profesní hodnoty a identita“. 
Jak je z tab. 9 zřejmé, pracovníci ministerstev se musejí každodenně a několikrát za týden (více než polovinu pracovní doby) potýkat s problémy, které vyžadují tvořivé řešení. Současně však jsou od této činnosti, vyžadující koncentraci, „odváděni“ “ řešením každodenních úkolů, pro které používáme označení „hašení požárů“. Výsledky zkoumání ukazuje tab. 10.

Tab. 10: Kolik procent respondentů odhadlo, jak velký podíl z jejich pracovního času zaberou činnosti, které by bylo možné označit za okamžité „hašení požárư“?

\begin{tabular}{|l|c|c|}
\hline \multicolumn{1}{|c|}{ Sledovaný ukazatel } & \multicolumn{2}{c|}{ Zkoumaná složka } \\
\hline $\begin{array}{l}\text { Podíl pracovního času potřebného } \\
\text { na okamžité řešení úloh (\%) }\end{array}$ & Ministerstvo obrany & Ministerstva celkem \\
\hline $51 \%$ a více & 9 & 8 \\
\hline $21-50 \%$ & 31 & 55 \\
\hline $1-20 \%$ & 54 & 9 \\
\hline $0 \%$ & 6 & 28 \\
\hline
\end{tabular}

Pramen: Vlastní výzkum v rámci projektu GAČR P 404/12/0725 „Analytici politiky v ústřední státní správě České republiky: praktiky, profesní hodnoty a identita“.

Činnosti označené „,hašení požárư“ lze považovat za protiklad strategické a koncepční činnosti. Jak je z tab. 10 zřejmé, v průměru osm procent dotázaných uvedlo, že ,,hašení požárů“ zabírá více než padesát procent jejich pracovního času. Dalších dvacet osm procent (v prŕípadě Ministerstva obrany 31 \%) uvedlo, že hašení požárů představuje jednu pětinu až jednu polovinu jejich pracovního času. To je poměrně nepříznivé zjištění, které potvrzuje tezi, že ministerstva jsou spíše „reaktivními““ orgány, kdy jejich odborní pracovníci jsou nuceni podstatnou část své pracovní doby věnovat řešení naléhavých každodenních (,právě se vynořivších“) problémů, nežli by byly „proaktivními““ orgány, které pracují s anticipací (předvídáním) budoucnosti a strategickým uvažováním a plánováním.

Ani pozice Ministerstva obrany není v tomto ohledu výjimkou. Bylo by vhodné, aby si samotná ministerstva $\mathrm{v}$ interním auditu činností prověřila, $\mathrm{v}$ čem spočívají příčiny tohoto stavu. Jsou to nedostatečné personální kapacity k realizaci úkolů, kdy zaměstnanci se dostávají k jejich řešení teprve tehdy, až jsou urgentní? Je to důsledek nekompetentních zásahů ,seshora?“'Je to výsledek nestabilního politického prostředí? Působí na tuto nestabilitu negativně politický cyklus, kdy primárním cílem politiků je být znovu zvolen, přičemž výhled rezortu za tímto obdobím je pro politika druhotným? Je skutečně pro politiky riskantní ke konci volebního období (a tím i ke konci setrvávání ve své funkci na ministerstvu) činit potřebné reformní změny, jejichž výsledky se však dostaví až v dalším politickém cyklu, kdy však existuje vysoké riziko, že „,smetanu za konečné výsledky slízne někdo jiný?““

To vše jsou možné faktory, které mohou negativně ovlivňovat činnost zaměstnanců ministerstva. Jsou to však pro samotné odborné zaměstnance faktory vnější, a tudíž jimi (ceteris paribus) neovlivnitelné. Žádoucí však je se jimi zabývat a změnit existující prostředí. Výsledky zkoumání totiž ukazují (viz tab. 11), že ministerstva nedisponují dostatečnými kapacitami pro dlouhodobé plánování a strategické činnosti s více než ročním horizontem. 
Tab. 11: Kolik procent respondentů odhadlo, jak velký podíl z jejich pracovního času zaberou činnosti, které by bylo možné označit za strategické činnosti (s více než ročním časovým horizontem)?

\begin{tabular}{|l|c|c|}
\hline \multicolumn{1}{|c|}{ Sledovaný ukazatel } & \multicolumn{2}{c|}{ Zkoumaná složka } \\
\hline $\begin{array}{l}\text { Podíl pracovního času na řešení } \\
\text { strategických činností (resp. činností } \\
\text { s více než ročním časovým horizontem) }\end{array}$ & Ministerstvo obrany & Ministerstva celkem \\
\hline $51 \%$ a více & 4 & 4 \\
\hline $21-50 \%$ & 17 & 15 \\
\hline $1-20 \%$ & 66 & 58 \\
\hline $0 \%$ & 13 & 23 \\
\hline
\end{tabular}

Pramen: Vlastní výzkum v rámci projektu GAČR P 404/12/0725 „Analytici politiky v ústřední státní správě České republiky: praktiky, profesní hodnoty a identita“".

Jak je z údajů tab. 11 zřejmé, pouze $4 \%$ dotazovaných uvedlo, že strategické činnosti zabývají více než polovinu jejich pracovního času. Přes osmdesát procent dotázaných (v prípadě Ministerstva obrany 79\%) uvedlo, že strategickým činnostem se věnují pouze jedno procento až pětinu svého pracovního času.

Jak je z výzkumu zřejmé, na ministerstva lze obecně říci, že strategickým činnostem s více než ročním horizontem se zaměstnanci věnují velmi málo. Jejich pracovní kapacity vyčerpávají činnosti, které patří někde mezi „hašení požárư“ a strategické činnosti, tj. operativní činnosti s horizontem jednoho roku. To potvrzuje tezi, že ministerstva ČR jsou systémově orientována „reaktivně“ a méně (málo) „proaktivně“ (anticipačně). Činnosti a podmínky $\mathrm{k}$ jejich provádění by měly být nastaveny tak, aby byly výrazně preventivní, a nikoliv operativně-,,hasící“, zaměřeny na řešení právě se objevivších problémů. Takové řešení (ve srovnání s prevencí) může být totiž opožděné a méně účinné (př́ípadně i neúčinné).

\section{Spokojenost respondentů s různými aspekty své práce}

Pro indikaci spokojenosti respondentů se svojí prací byly zvoleny ukazatele jistoty zaměstnání, délky pracovní doby, organizace pracovní doby (včetně příchodů, odchodů, přestávek), vztahů s přímým nadřízeným, pracovní zátěže, možnosti povýšení, možnosti profesního rozvoje, platového ohodnocení, vztahů v pracovním kolektivu a zaměstnaneckých výhod. Prvním zkoumaným ukazatelem je spokojenost respondentů s jejich prací, pokud jde o jistotu zaměstnání. Výsledky zkoumání ukazuje tab. 12.

Tab. 12: Spokojenost respondentů s jejich prací, pokud jde o jistotu zaměstnání

\begin{tabular}{|l|c|c|}
\hline \multicolumn{1}{|c|}{ Sledovaný ukazatel } & \multicolumn{2}{c|}{ Zkoumaná složka } \\
\hline Stupeň spokojenosti (podíl v \%) & Ministerstvo obrany & Ministerstva celkem \\
\hline Rozhodně spokojen(a) & 28 & 30 \\
\hline Spíše spokojen(a) & 40 & 43 \\
\hline Ani spokojen(a), ani nespokojen(a) & 18 & 16 \\
\hline
\end{tabular}




\begin{tabular}{|l|c|c|}
\hline \multicolumn{1}{|c|}{ Sledovaný ukazatel } & \multicolumn{2}{c|}{ Zkoumaná složka } \\
\hline Stupeň spokojenosti (podíl v \%) & Ministerstvo obrany & Ministerstva celkem \\
\hline Spíše nespokojen(a) & 10 & 8 \\
\hline Rozhodně nespokojen(a) & 4 & 3 \\
\hline
\end{tabular}

Pramen: Vlastní výzkum v rámci projektu GAČR P 404/12/0725 „Analytici politiky v ústřední státní správě České republiky: praktiky, profesní hodnoty a identita“.

Jak je z výsledků výzkumu zřejmé, tři čtvrtiny respondentů uvedlo, že jsou rozhodně nebo spíše spokojeni. Ministerstvo obrany se v tomto ohledu neliší od průměrných ukazatelů. Rozhodně nespokojených zaměstnanců je pouze několik procent. V prŕípadě Ministerstva obrany jsou to čtyři procenta dotázaných. Ukazatel zajímavosti práce (viz následující tab. 13) indikuje, že většina respondentů je spokojena z pohledu zajímavosti své práce. V př́padě Ministerstva obrany je spokojených $87 \%$ dotázaných. Rozhodně nespokojených je pouhé jedno procento dotazovaných.

Tab. 13: Spokojenost respondentů s jejich prací, pokud jde o zajímavost práce

\begin{tabular}{|l|c|c|}
\hline \multicolumn{1}{|c|}{ Sledovaný ukazatel } & \multicolumn{2}{c|}{ Zkoumaná složka } \\
\hline Stupeň spokojenosti (podíl v \%) & Ministerstvo obrany & Ministerstva celkem \\
\hline Rozhodně spokojen(a) & 45 & 48 \\
\hline Spíše spokojen(a) & 42 & 12 \\
\hline Ani spokojen(a), ani nespokojen(a) & 8 & 5 \\
\hline Spíše nespokojen(a) & 4 & 1 \\
\hline Rozhodně nespokojen(a) & 1 & 44 \\
\hline
\end{tabular}

Pramen: Vlastní výzkum v rámci projektu GAČR P 404/12/0725 „Analytici politiky v ústřední státní správě České republiky: praktiky, profesní hodnoty a identita“.

V ukazateli spokojenosti s prací, pokud jde o délku pracovní doby, byl zjištěn stav, který ukazuje tab. 14.

Tab. 14: Spokojenost respondentů s jejich prací, pokud jde o délku pracovní doby

\begin{tabular}{|l|c|c|}
\hline \multicolumn{1}{|c|}{ Sledovaný ukazatel } & \multicolumn{2}{c|}{ Zkoumaná složka } \\
\hline Stupeň spokojenosti (podíl v \%) & Ministerstvo obrany & Ministerstva celkem \\
\hline Rozhodně spokojen(a) & 38 & 33 \\
\hline Spíše spokojen(a) & 48 & 17 \\
\hline Ani spokojen(a), ani nespokojen(a) & 11 & 5 \\
\hline Spíše nespokojen(a) & 2 & 2 \\
\hline Rozhodně nespokojen(a) & 1 & 23 \\
\hline
\end{tabular}

Pramen: Výzkumné šetření pracovníků centrální státní správy (ministerstev) a př́mo řízených organizací. Závěrečná zpráva. Zář́ 2013. Výzkum v rámci projektu GAČR P 404/12/0725 „Analytici politiky v ústřední státní správě České republiky:praktiky, profesní hodnoty a identita“.

Z pohledu ukazatele délky pracovní doby panuje relativně velká spokojenost, kdy relativně spokojených je v průměru více než čtyři pětiny dotázaných. Respondenti 
Ministerstva obrany prokazují v $86 \%$ dotazovaných spokojenost, což je nad celkovým průměrem ( $76 \%$ spokojenost) všech ministerstev. V př́ípadě Ministerstva obrany je rozhodně nespokojených pouhé jedno procento.

Pokud se jedná o organizaci pracovní doby, příchody, odchody, přestávky, výsledky zkoumání ukazuje tab. 15.

Tab. 15: Spokojenost respondentů s jejich prací, pokud jde o organizaci pracovní doby, příchody, odchody, přestávky

\begin{tabular}{|l|c|c|}
\hline \multicolumn{1}{|c|}{ Sledovaný ukazatel } & \multicolumn{2}{c|}{ Zkoumaná složka } \\
\hline Stupeň spokojenosti (podíl v \%) & Ministerstvo obrany & Ministerstva celkem \\
\hline Rozhodně spokojen(a) & 42 & 39 \\
\hline Spíše spokojen(a) & 48 & 39 \\
\hline Ani spokojen(a), ani nespokojen(a) & 5 & 10 \\
\hline Spíše nespokojen(a) & 4 & 9 \\
\hline Rozhodně nespokojen(a) & 1 & 3 \\
\hline
\end{tabular}

Pramen: Vlastní výzkum v rámci projektu GAČR P 404/12/0725 „Analytici politiky v ústřední státní správě České republiky: praktiky, profesní hodnoty a identita“.

Jak je z tab. 15 zřejmé, velká část respondentů vyjádřila spokojenost ohledně organizace pracovní doby. V př́ípadě Ministerstva obrany vyjádřilo relativní spokojenost $90 \%$ dotazovaných a relativní nespokojenost pouze $5 \%$ respondentů. Výzkum však ukazuje rozdíly mezi jednotlivými ministerstvy. Faktory této nespokojenosti by si vyžadovaly další výzkum.

Stav spokojenosti zaměstnanců s jejich prací, pokud se jedná o vztahy s přímým nadř́zeným, ukazuje tab. 16.

Tab. 16: Spokojenost respondentů s jejich prací, pokud jde o vztahy s př́mým nadřizeným

\begin{tabular}{|c|c|c|}
\hline Sledovaný ukazatel & \multicolumn{2}{|c|}{ Zkoumaná složka } \\
\hline Stupeň spokojenosti (podíl v \%) & Ministerstvo obrany & Ministerstva celkem \\
\hline Rozhodně spokojen(a) & 51 & 55 \\
\hline Spíše spokojen(a) & 34 & 30 \\
\hline Ani spokojen(a), ani nespokojen(a) & 8 & 7 \\
\hline Spíše nespokojen(a) & 5 & 5 \\
\hline Rozhodně nespokojen(a) & 2 & 2 \\
\hline Poznámka & & $\begin{array}{l}\text { Zbývající jedno procento } \\
\text { je rovnoměrně rozloženo } \\
\text { v jednotlivých položkách. }\end{array}$ \\
\hline
\end{tabular}

Pramen: Vlastní výzkum v rámci projektu GAČR P 404/12/0725 „Analytici politiky v ústřední státní správě České republiky: praktiky, profesní hodnoty a identita“.

Dotazovaní zaměstnanci zkoumaných ministerstev celkově vyjádřili velkou spokojenost, kdy více než čtyři pětiny dotázaných vyjádřili relativní spokojenost. Mezi jednotlivými ministerstvy nebyly podstatné rozdíly. 
Výsledky zkoumání týkající se spokojenosti respondentů pokud jde o možnost povýšení ukazuje tab. 17.

Tab. 17: Spokojenost respondentů s jejich prací, pokud jde o možnost povýšení

\begin{tabular}{|l|c|c|}
\hline \multicolumn{1}{|c|}{ Sledovaný ukazatel } & \multicolumn{2}{c|}{ Zkoumaná složka } \\
\hline Stupeň spokojenosti (podíl v \%) & Ministerstvo obrany & Ministerstva celkem \\
\hline Rozhodně spokojen(a) & 13 & 21 \\
\hline Spíše spokojen(a) & 27 & 45 \\
\hline Ani spokojen(a), ani nespokojen(a) & 41 & 16 \\
\hline Spíše nespokojen(a) & 14 & 9 \\
\hline Rozhodně nespokojen(a) & 5 & 9 \\
\hline
\end{tabular}

Pramen: Vlastní výzkum v rámci projektu GAČR P 404/12/0725 „Analytici politiky v ústřední státní správě České republiky: praktiky, profesní hodnoty a identita“.

Z celkového pohledu je $\mathrm{v}$ tomto ukazateli spokojena přibližně třetina dotazovaných, přičemž v prŕípadě Ministerstva obrany je spokojenost nejvyšší, kdy dosahuje $40 \%$. To může být pravděpodobně dáno tím, že ze srovnávaných ministerstev má Ministerstvo obrany nejpropracovanější systém povyšování. Na straně druhé je zajímavé, že 41 \% dotazovaných pracovníků Ministerstva obrany není spokojena ani nespokojena.

V ukazateli spokojenosti respondentů s jejich prací, pokud jde o možnost profesního rozvoje byla spokojenost respondentů o něco vyšší, jak ukazuje tab. 18.

Tab. 18: Spokojenost respondentů s jejich prací, pokud jde o možnost profesního rozvoje

\begin{tabular}{|l|c|c|}
\hline \multicolumn{1}{|c|}{ Sledovaný ukazatel } & \multicolumn{2}{c|}{ Zkoumaná složka } \\
\hline Stupeň spokojenosti (podíl v \%) & Ministerstvo obrany & Ministerstva celkem \\
\hline Rozhodně spokojen(a) & 12 & 13 \\
\hline Spíše spokojen(a) & 44 & 38 \\
\hline Ani spokojen(a), ani nespokojen(a) & 23 & 25 \\
\hline Spíše nespokojen(a) & 16 & 17 \\
\hline Rozhodně nespokojen(a) & 4 & 7 \\
\hline Poznámka & $\begin{array}{l}\text { Zbývající jedno procento } \\
\text { je rovnoměrně rozloženo } \\
\text { v jednotlivých položkách. }\end{array}$ \\
\hline
\end{tabular}

Pramen: Vlastní výzkum v rámci projektu GAČR P 404/12/0725 „Analytici politiky v ústřední státní správě České republiky: praktiky, profesní hodnoty a identita“.

$\mathrm{Z}$ údajů v tab. 18 je zřejmé, že přibližně polovina dotázaných respondentů na ministerstvech vyjádřila relativní spokojenost s možnostmi profesního rozvoje. V př́ípadě Ministerstva obrany vyjádřilo spokojenost $56 \%$ dotazovaných, přičemž jedna pětina dotazovaných vyjádřila relativní nespokojenost. $Z$ toho pouhá čtyři procenta respondentů vyjádřila rozhodnou nespokojenost. Lze konstatovat, že v tomto ohledu se Ministerstvo obrany nijak nevymyká průměrnému stavu.

Další analýza se soustředila na sledování spokojenosti respondentů, pokud se týká jejich platového ohodnocení. Výsledky zkoumání ukazuje tab. 19. 
Tab. 19: Spokojenost respondentů s jejich prací, pokud jde o platové ohodnocení

\begin{tabular}{|l|c|c|}
\hline \multicolumn{1}{|c|}{ Sledovaný ukazatel } & \multicolumn{2}{c|}{ Zkoumaná složka } \\
\hline Stupeň spokojenosti (podíl v \%) & Ministerstvo obrany & Ministerstva celkem \\
\hline Rozhodně spokojen(a) & 91 & 37 \\
\hline Spíše spokojen(a) & 24 & 25 \\
\hline Ani spokojen(a), ani nespokojen(a) & 20 & 22 \\
\hline Spíše nespokojen(a) & 5 & 8 \\
\hline Rozhodně nespokojen(a) & $\begin{array}{l}\text { Zbývající jedno procento } \\
\text { je rovnoměrně rozloženo } \\
\text { v jednotlivých položkách. }\end{array}$ \\
\hline Poznámka & \multicolumn{2}{|c|}{} \\
\hline
\end{tabular}

Pramen: Vlastní výzkum v rámci projektu GAČR P 404/12/0725,„Analytici politiky v ústřední státní správě České republiky: praktiky, profesní hodnoty a identita“.

Jak je z údajů v tab. 19 zřejmé, spokojenost vyjádřilo $45 \%$ dotazovaných. $V$ př́padě Ministerstva obrany to byla přesně polovina dotazovaných. Relativní nespokojenost vyjádřila čtvrtina dotazovaných, přičemž rozhodně nespokojených je $5 \%$ dotazovaných. Ministerstvo obrany je v tomto ukazateli mírně nad průměrem všech ministerstev, kdy relativní nespokojenost vyjádřilo $30 \%$ dotazovaných, přičemž rozhodně nespokojených je $8 \%$ dotázaných pracovníků ministerstev.

Na výsledky zkoumání spokojenosti respondentů pokud jde o vztahy v pracovním kolektivu, ukazuje tab. 20.

Tab. 20: Spokojenost respondentů s jejich prací, pokud jde o vztahy v pracovním kolektivu

\begin{tabular}{|l|c|c|}
\hline \multicolumn{1}{|c|}{ Sledovaný ukazatel } & \multicolumn{2}{c|}{ Zkoumaná složka } \\
\hline Stupeň spokojenosti (podíl v \%) & Ministerstvo obrany & Ministerstva celkem \\
\hline Rozhodně spokojen(a) & 41 & 46 \\
\hline Spíše spokojen(a) & 43 & 38 \\
\hline Ani spokojen(a), ani nespokojen(a) & 10 & 10 \\
\hline Spíše nespokojen(a) & 6 & 5 \\
\hline Rozhodně nespokojen(a) & 0 & 1 \\
\hline
\end{tabular}

Pramen: Vlastní výzkum v rámci projektu GAČR P 404/12/0725,„Analytici politiky v ústřední státní správě České republiky: praktiky, profesní hodnoty a identita“.

Jak je z údajů tab. 20 zřejmé, spokojenost se vztahy v pracovním kolektivu je na ministerstvech velmi vysoká. V průměru dosahuje $84 \%$ relativní spokojenosti. Na Ministerstvu obrany je relativní spokojenost se vztahy v pracovním kolektivu rovněž $84 \%$, spíše nespokojeno je pouze $6 \%$. Z hlediska ukazatele spokojenosti respondentů, pokud jde o zaměstnanecké výhody, jsou výsledky zkoumání uvedeny v následující tabulce č. 21 . 
Tab. 21: Spokojenost respondentů s jejich prací, pokud jde o zaměstnanecké výhody v pracovním kolektivu

\begin{tabular}{|l|c|c|}
\hline \multicolumn{1}{|c|}{ Sledovaný ukazatel } & \multicolumn{2}{c|}{ Zkoumaná složka } \\
\hline Stupeň spokojenosti (podíl v \%) & Ministerstvo obrany & Ministerstva celkem \\
\hline Rozhodně spokojen(a) & 9 & 33 \\
\hline Spíše spokojen(a) & 40 & 34 \\
\hline Ani spokojen(a), ani nespokojen(a) & 33 & 17 \\
\hline Spíše nespokojen(a) & 13 & 6 \\
\hline Rozhodně nespokojen(a) & 5 & 6 \\
\hline
\end{tabular}

Pramen: Vlastní výzkum v rámci projektu GAČR P 404/12/0725 „Analytici politiky v ústřední státní správě České republiky: praktiky, profesní hodnoty a identita“.

Jak je z údajů zř̉ejmé, spokojenost vyjádřila necelá polovina dotazovaných (celkem 43 \%). Respondenti Ministerstva obrany uvádějí 49\% relativní spokojenost.

\section{Analýza podmínek práce a ochota setrvání v rezortu Ministerstva obrany}

Další okruh otázek směřoval na zkoumání podmínek výkonu práce. Byly sledovány tyto ukazatele: znalosti a dovednosti pro zvládnutí úkolů, dostatek času pro kvalitní výkon práce, psychická náročnost práce, dostatek př́ležitostí k rozšiřování znalostí a dovedností, pocit užitečnosti práce, hrdost na práci na ministerstvu, vliv politických zájmů na práci.

Výsledky zkoumání v oblasti znalosti a dovednosti pro zvládnutí úkolů ukazuje tab. 22.

Tab. 22: Do jaké míry souhlasí respondenti s výrokem: Mám dostatek znalostí a dovedností pro zvládnutí úkolů, které jsou mi přiděleny.

\begin{tabular}{|l|c|c|}
\hline \multicolumn{1}{|c|}{ Sledovaný ukazatel } & \multicolumn{2}{c|}{ Zkoumaná složka } \\
\hline Postoj (podíl v \%) & Ministerstvo obrany & Ministerstva celkem \\
\hline Rozhodně ano & 46 & 45 \\
\hline Spíše ano & 49 & 49 \\
\hline Ani ano ani ne & 3 & 4 \\
\hline Spíše ne & 2 & 2 \\
\hline Rozhodně ne & 0 & 0 \\
\hline
\end{tabular}

Pramen: Vlastní výzkum v rámci projektu GAČR P 404/12/0725 „Analytici politiky v ústřední státní správě České republiky: praktiky, profesní hodnoty a identita“.

Jak je z výsledků výzkumu zřejmé, v průměru 94\% dotazovaných uvádí, že má dostatek znalostí a dovedností k výkonu stanovených úkolů. To platí i pro Ministerstvo obrany, kde $95 \%$ respondentů uvádí, že nemá pocit, že jim jsou zadávány úkoly nad rámce jejich znalostí a dovedností. Pouhá dvě procenta respondentů vyjadřují, že spíše tyto znalosti a dovednosti nemají. Celkově lze tedy konstatovat, že dotazovaní pracovníci Ministerstva obrany jsou vzdělanostně a dovednostně kompetentní k výkonu svých funkcí. 
Dalším sledovaným ukazatelem byl dostatek času pro kvalitní výkon práce. Výsledky zkoumání ukazuje tab. 23.

Tab. 23: Do jaké míry souhlasí respondenti s výrokem: Mám dostatek času pro kvalitní výkon práce

\begin{tabular}{|l|c|c|}
\hline \multicolumn{1}{|c|}{ Sledovaný ukazatel } & \multicolumn{2}{c|}{ Zkoumaná složka } \\
\hline Postoj (podíl v \%) & Ministerstvo obrany & Ministerstva celkem \\
\hline Rozhodně ano & 15 & 18 \\
\hline Spíše ano & 41 & 43 \\
\hline Ani ano ani ne & 20 & 18 \\
\hline Spíše ne & 22 & 3 \\
\hline Rozhodně ne & 2 & 18 \\
\hline
\end{tabular}

Pramen: Vlastní výzkum v rámci projektu GAČR P 404/12/0725 „Analytici politiky v ústřední státní správě České republiky: praktiky, profesní hodnoty a identita“".

Souhlas s tím, že pracovníci mají dostatek času pro kvalitní výkon práce, vyjádřilo v průměru $61 \%$ dotazovaných. Respondenti Ministerstva obrany souhlasí s tímto tvrzením v 56 procentech př́ípadů.

Co týká celkového zobecňujícího pohledu na všechna ministerstva, dá se pravděpodobně usuzovat, že dotazovaní zaměstnanci na jedné straně nemají pocit, že by měli dostatek času pro kvalitní výkon práce, na straně druhé však ani silně nepocit’ují nedostatek času pro kvalitní výkon své práce.

Další otázka prověřovala dostatek informací pro kvalitní výkon práce. Výsledky zkoumání ukazuje tab. 24.

Tab. 24: Do jaké míry souhlasí respondenti s výrokem: Mám dostatek informací pro kvalitní výkon práce

\begin{tabular}{|l|c|c|}
\hline \multicolumn{1}{|c|}{ Sledovaný ukazatel } & \multicolumn{2}{c|}{ Zkoumaná složka } \\
\hline Postoj (podíl v \%) & Ministerstvo obrany & Ministerstva celkem \\
\hline Rozhodně ano & 9 & 13 \\
\hline Spíše ano & 22 & 23 \\
\hline Ani ano ani ne & 9 & 10 \\
\hline Spíše ne & 1 & 1 \\
\hline Rozhodně ne & 23 \\
\hline Poznámka & $\begin{array}{l}\text { Zbývající jedno procento } \\
\text { je rovnoměrně rozloženo } \\
\text { v jednotlivých položkách. }\end{array}$ \\
\hline
\end{tabular}

Pramen: Vlastní výzkum v rámci projektu GAČR P 404/12/0725 „Analytici politiky v ústřední státní správě České republiky: praktiky, profesní hodnoty a identita“.

Jak je z tab. 24 zřejmé, s výrokem, že dotazovaný má dostatek informací pro kvalitní výkon práce, v průměru souhlasily dvě třetiny respondentů. Ministerstvo obrany se v tomto ohledu neliší od průměrného stavu.

Pouze jedna desetina dotazovaných z Ministerstva obrany odpověděla, že nemá dostatek informací pro kvalitní výkon práce. 
Při prověřování psychické náročnosti práce přes polovinu všech dotazovaných hodnotí, že jejich práce je psychicky náročná. V prrípadě Ministerstva obrany jsou to dvě třetiny dotazovaných. Tuto odlišnost lze v př́padě Ministerstva obrany pravděpodobně vysvětlit tím, že psychická náročnost je dána samotnou povahou komplexnosti práce na Ministerstvu obrany. Také se lze domnívat, že každé ministerstvo má „svůj vnitřní druh kultury prŕístupu k práci“, čemuž v př́ipadě Ministerstva obrany odpovídá relativně „silný vojenský duch odpovědnosti“ pro řešení svěřených úkoli̊, což může být jedním z faktorů, který podněcuje psychickou náročnost k plnění svěřených úkolů. Prověření této hypotézy by si vyžadovalo samostatný výzkum. Verifikace této hypotézy byla mimo rámec výzkumného projektu.

Dalším prověřovaným problémem bylo, zda respondenti mají dostatek příležitostí k rozšiřování znalostí a dovedností. Výsledky zkoumání ukazuje tab. 25.

Tab. 25: Do jaké míry souhlasí respondenti s výrokem: Mám dostatek příležitostí k neustálému rozšiřování znalostí a dovedností.

\begin{tabular}{|l|c|c|}
\hline \multicolumn{1}{|c|}{ Sledovaný ukazatel } & \multicolumn{2}{c|}{ Zkoumaná složka } \\
\hline Postoj (podíl v \%) & Ministerstvo obrany & Ministerstva celkem \\
\hline Rozhodně ano & 12 & 14 \\
\hline Spíše ano & 42 & 40 \\
\hline Ani ano ani ne & 26 & 22 \\
\hline Spíše ne & 17 & 20 \\
\hline Rozhodně ne & 3 & 4 \\
\hline
\end{tabular}

Pramen: Vlastní výzkum v rámci projektu GAČR P 404/12/0725 „Analytici politiky v ústřední státní správě České republiky: praktiky, profesní hodnoty a identita“.

Výsledky zkoumání uvedené v tab. 25 ukazují, že Ministerstvo obrany se z hlediska souhlasu s výrokem o dostatku příležitostí k neustálému rozšiřování znalostí a dovedností nijak neliší od celkového stavu. Jak v případě „,ministerstev celkem“, tak i na Ministerstvu obrany, s tímto výrokem souhlasí 54\% dotazovaných. Nespokojena je jedna pětina dotazovaných respondentů Ministerstva obrany. V prŕípadě celkového stavu je nespokojených jedna čtvrtina dotazovaných pracovníků ministerstev.

Výsledky zjištění pocitu užitečnosti z vykonávané práce ukazuje tab. 26.

Tab. 26: Do jaké míry souhlasí respondenti s výrokem: Mám pocit, že dělám užitečnou práci.

\begin{tabular}{|l|c|c|}
\hline \multicolumn{1}{|c|}{ Sledovaný ukazatel } & \multicolumn{2}{c|}{ Zkoumaná složka } \\
\hline Postoj (podíl v \%) & Ministerstvo obrany & Ministerstva celkem \\
\hline Rozhodně ano & 26 & 25 \\
\hline Spíše ano & 50 & 45 \\
\hline Ani ano ani ne & 15 & 20 \\
\hline Spíše ne & 7 & 8 \\
\hline Rozhodně ne & 2 & 2 \\
\hline
\end{tabular}

Pramen: Vlastní výzkum v rámci projektu GAČR P 404/12/0725 „Analytici politiky v ústřední státní správě České republiky: praktiky, profesní hodnoty a identita“. 
Jak je z údajů v tab. 26 zřejmé, v průměru $70 \%$ dotazovaných respondentů má pocit, že vykonává užitečnou práci. V prŕípadě Ministerstva obrany tento pocit užitečnosti sdílí tři čtvrtiny dotazovaných a pouze necelá desetina dotazovaných $(9 \%)$ nemá pocit užitečnosti z vykonávání své práce. Znamená to, že pouze každý desátý dotazovaný si myslí, že nedělá užitečnou práci.

Další zjištění bylo orientováno na pocit hrdosti respondenta, že pracuje na ministerstvu. Výsledky zkoumání ukazuje tab. 27.

Tab. 27: Do jaké míry souhlasí respondenti s výrokem: Jsem hrdý(á) na to, že pracuji na ministerstvu

\begin{tabular}{|l|c|c|}
\hline \multicolumn{1}{|c|}{ Sledovaný ukazatel } & \multicolumn{2}{c|}{ Zkoumaná složka } \\
\hline Postoj (podíl v \%) & Ministerstvo obrany & Ministerstva celkem \\
\hline Rozhodně ano & 33 & 22 \\
\hline Spíše ano & 38 & 36 \\
\hline Ani ano ani ne & 23 & 8 \\
\hline Spíše ne & 4 & 3 \\
\hline Rozhodně ne & 1 & \\
\hline Poznámka & $\begin{array}{l}\text { Zbývající jedno procento } \\
\text { je rovnoměrně rozloženo } \\
\text { v jednotlivých položkách. }\end{array}$ \\
\hline
\end{tabular}

Pramen: Vlastní výzkum v rámci projektu GAČR P 404/12/0725 „Analytici politiky v ústřední státní správě České republiky: praktiky, profesní hodnoty a identita“.

S výrokem hrdosti o práci na ministerstvu v průměru souhlasí přibližně polovina dotazovaných. Ministerstvo obrany se poměrně výrazně liší, kdy pocit hrdosti sdílí $71 \%$ dotazovaných (v prrípadě všech ministerstev je to pouze $58 \%$ ) a pouze v prŕípadech $5 \%$ tuto hrdost zkoumaný vzorek pracovníků Ministerstva obrany nepocit’uje. V př́padě všech ministerstev hrdost nepocit'uje $11 \%$ dotazovaných. Podstatný rozdíl je možné vysvětlit z vědomí a vnitřního pocitu důležitosti pracovníků rezortu Ministerstva obrany, že pracují v takové oblasti státní správy, která je klíčová pro zajištění bezpečnosti (obranu) státu. Vysoký stupeň hrdosti může být ovlivněn i pocitem účasti na zabezpečování alianční obrany. Jsou to však jen hypotézy, které mohou být ověřeny vnitřním výzkumem.

Zajímavým faktorem bylo zjištění, nakolik ovlivňují politické zájmy práci dotazovaných. Výsledky zkoumání ukazuje tab. 28.

Tab. 28: Do jaké míry souhlasí respondenti s výrokem: Má práce je často ovlivněna politickými zájmy.

\begin{tabular}{|l|c|c|}
\hline \multicolumn{1}{|c|}{ Sledovaný ukazatel } & \multicolumn{2}{c|}{ Zkoumaná složka } \\
\hline Postoj (podíl v \%) & Ministerstvo obrany & Ministerstva celkem \\
\hline Rozhodně ano & 8 & 12 \\
\hline Spíše ano & 21 & 23 \\
\hline Ani ano ani ne & 20 & 19 \\
\hline Spíše ne & 25 & 23 \\
\hline Rozhodně ne & 26 & 23 \\
\hline
\end{tabular}

Pramen: Vlastní výzkum v rámci projektu GAČR P 404/12/0725 „Analytici politiky v ústřední státní správě České republiky: praktiky, profesní hodnoty a identita“. 
Jak je z výsledků výzkumu zřejmé, pocit ovlivňování práce politickými zájmy sdílí přibližně jedna třetina dotazovaných (35\%). Na Ministerstvu obrany tento pocit sdílí 29 \%. Je zřejmé, že Ministerstvo obrany je tím ministerstvem, kde velká část zaměstnanců nepocit’uje silný vliv politických zájmů na svou práci, avšak zároveň přibližně jedna třetina respondentů dopad politického zájmu na svoji práci pocit’uje. Relativně odlišné postavení Ministerstva obrany je pravděpodobně dáno specifikou zajišt’ování (kolektivní) bezpečnosti, kdy všechny koaliční vládnoucí (či potenciálně koaličně vládnoucí) parlamentní strany se shodují v potřebě zajištění obrany České republiky v rámci alianční obrany.

\section{Perspektivy setrvání a poptávka po dalším vzdělávání}

Závěrečnou výzkumnou oblastí byla problematika perspektiv setrvání v pracovním poměru u svého dosavadního zaměstnavatele a poptávka po dalším vzdělávání. Výsledky zjištění perspektiv setrvání v pracovním poměru u svého dosavadního zaměstnavatele ukazuje tab. 29.

Tab. 29: Odpovědi na otázku: Jak dlouho chcete setrvat v pracovním poměru u svého současného zaměstnavatele?

\begin{tabular}{|l|c|c|}
\hline \multicolumn{1}{|c|}{ Sledovaný ukazatel } & \multicolumn{2}{c|}{ Zkoumaná složka } \\
\hline Počet let (podíl v \%) & Ministerstvo obrany & Ministerstva celkem \\
\hline Více než 10 let & 13 & 16 \\
\hline 6-10 let & 21 & 26 \\
\hline 3-5 let & 36 & 14 \\
\hline 1-2 roky & 13 & 6 \\
\hline Méně než 1 rok & 6 & 25 \\
\hline Nevím & 11 & 13 \\
\hline
\end{tabular}

Pramen: Vlastní výzkum v rámci projektu GAČR P 404/12/0725 „Analytici politiky v ústřední státní správě České republiky: praktiky, profesní hodnoty a identita“.

Výsledky zkoumání ukazují, že necelá třetina dotazovaných chce setrvat u svého zaměstnavatele více jak šest let. Jedna pětina maximálně dva roky. V prrípadě Ministerstva obrany chce více jak šest let setrvat v rezortu 34 \% dotazovaných. Jak je z výzkumu zřejmé, ve srovnání s jinými ministerstvy poměrně vysoké procento dotazovaných pracovníků Ministerstva obrany (36\%) plánuje s perspektivou zůstat v rezortu 3-5 let. To může mít různé přičiny, na které dovedou spolehlivě odpovědět personalisti Ministerstva obrany. První příčinou může být charakter závazků (smluv na danou dobu) s následným očekávaným odchodem mimo Ministerstvo obrany. Délka setrvání může být (,podvědomě“) ovlivněna i ,přirozeným“ faktorem, jímž je věk dotazovaných, kteří svoje setrvání na ministerstvu limitují věkem (např. odchodem do důchodu). Co však je možné pravděpodobně s vysokou pravděpodobností tvrdit je, že na relativní nestabilitu negativně působí neexistence (resp. odložená účinnost) zákona o státních zaměstnancích. 
Perspektivy zaměstnanců ministerstev ovlivňuje i systém a dostupnost dalšího vzdělávání. Výsledky zkoumání ukazuje následující tab. 30.

Tab. 30: Kolik procent respondentů absolvovalo další vzdělávání v následujících oblastech?

\begin{tabular}{|l|c|c|}
\hline \multicolumn{1}{|c|}{ Sledovaný ukazatel } & \multicolumn{2}{c|}{ Zkoumaná složka } \\
\hline Oblast (podíl v \%) & Ministerstvo obrany & Ministerstva celkem \\
\hline Politiky EU & 20 & 35 \\
\hline $\begin{array}{l}\text { Manažerské dovednosti (projektový } \\
\text { management, řízení lidských zdrojů) }\end{array}$ & 36 & 33 \\
\hline Strategické ř́zení a plánování & 35 & 22 \\
\hline $\begin{array}{l}\text { Komunikace s veřejností nebo } \\
\text { zapojování veřejnosti, mediace, facilitace }\end{array}$ & 16 & 22 \\
\hline $\begin{array}{l}\text { Metody analýzy a tvorby veřejných } \\
\text { politik }\end{array}$ & 11 & 10 \\
\hline Vůdcovství, leadership & 13 & 9 \\
\hline Evaluace veřejných politika programů & 4 & 8 \\
\hline Jiná aktivita & 62 & 56 \\
\hline
\end{tabular}

Pramen: Vlastní výzkum v rámci projektu GAČR P 404/12/0725 „Analytici politiky v ústřední státní správě České republiky: praktiky, profesní hodnoty a identita“.

Jak je z uvedených údajů zřejmé, poptávka pracovníků jednotlivých ministerstev po jednotlivých tematických vzdělávacích oblastech se liší. Je to přirozeně dané jednak specifikou ministerstev, a taktéž i poptávkou zaměstnanců po poznatcích, které jsou potřebné pro kvalitní výkon jejich práce. Svědčí o tom i samotné Ministerstvo obrany, které ve srovnání s ostatními ministerstvy poptává relativně málo problematiku politik EU, a na straně druhé nejvíce poptává problematiku strategického rízení a plánování. Z uvedených zjištění nelze činit žádné strukturní srovnávací závěry. Je však možné dané informace využívat jako zdroj informací pro tvorbu vzdělávacích plánů a aktivit či spíše jako inspiraci pro provedení vlastního průzkumu ke zjištění poptávky pracovníků po dalším vzdělávání.

\section{Závěr}

Zjištěný stav indikuje řadu problémů, z nichž některé si žádají naléhavé řešení. Některé z těchto problémů se týkají státní správy jako celku. Jejich řešení tudíž patř́i do kompetence exekutivy a zákonodárců. Jiné problémy se týkají samotného Ministerstva obrany. Jejich řešením by se měli zabývat vrcholoví řídící pracovníci Ministerstva obrany.

První skupina problémů se týká zjištění v oblasti věkové struktury dotazovaných. Výzkum prokazuje, že jednotlivá ministerstva se liší průměrným věkem i věkovou strukturou zkoumané skupiny pracovníků. Ministerstvo obrany má nejvyšší věkový průměr u zkoumané skupiny pracovníků, kde polovina pracovníků zkoumané skupiny je starší 50 let, přičemž polovina ze všech dotázaných zaměstnanců všech ministerstev je mladší 42 let. Vysvětlení tohoto stavu, vedle již zmiňované specifiky některých (vojenských) analytických a koncepčních činností, spatřuji i v dalších významných vlivech. 
Věkový průměr ministerstev výrazně ovlivňují „mladá ministerstva“, k nimž například patří Ministerstvo práce a sociálních věcí s mediánem věku 35 let a Ministerstvo financí s mediánem věku 37 let. To jsou zároveň dvě typická ministerstva, na nichž bych chtěl v kontextu s věkem Ministerstva obrany vysvětlit podstatu ,věkového problému“ Ministerstva obrany. Nízký věkový průměr u zmíněných ministerstev je dán tím, že do pracovních analytických pozicí u těchto ministerstev nastupují lidé po skončení vysokoškolských studií, tedy přibližně ve věku 25 let. Personalisté Ministerstva obrany mohou vedení rezortu Ministerstva obrany poskytnout informaci, v kolika letech se na tyto pozice dostávají absolventi vysokých vojenských škol od doby, kdy končí svá vysokoškolská studia...?

Na základě jejich odpovědi snadno porozumíme skutečnosti, že např. Ministerstvo financí patří mezi „mladá ministerstva“, ale zároveň pro zkoumaný vzorek Ministerstva financí je charakteristické, že pětinu zkoumaného vzorku tvoří pracovníci nad 60 let. I dalších několik ministerstev vykazuje podobný vysoký podíl této věkové skupiny. V př́ipadě Ministerstva obrany podíl věkové skupiny nad 60 let činí nejméně ze všech ministerstev - a to pouhých 8 procent. Pokud chtějí řídící pracovníci Ministerstva obrany změnit věkový průměr celé zkoumané skupiny zaměstnanců, musí nalézt způsob, jak změnit parametry vstupu té části absolventů vysokých vojenských škol (resp. mladých uchazečů o dané posty), aby tito mohli zaujmout pracovní pozice tam, kde nejsou nutné předchozí vojenské zkušenosti.

Problém vysokého věku zkoumané skupiny pracovníků Ministerstva obrany je ještě významně ovlivněn dalšími faktory, které ukazují na to, že za daných (jinak nezměněných podmínek) není možné převzít model, který uplatňují „mladá ministerstva“. Z praxe vysokoškolského pedagoga, který se pedagogicky dostává do kontaktu se studenty na Vysoké škole ekonomické (tito studenti se stávají po skončení studia analytiky Ministerstva financí) a se studenty na Fakultě sociálních věd Univerzity Karlovy (ucházejí se po skončení studia o práci na Ministerstvu práce a sociálních věcí), mohu říci, že tito studenti jsou úspěšní v získávání daných analytických a koncepčních pracovních pozicí. Proč tomu tak je? Vysvětlení je poměrně jednoduché. Dotyční studenti, podotýkám, že se jedná o studenty denního studia, nikoli kombinovaného (dříve nazývaného dálkového) studia, totiž již počas svých studií na daném ministerstvu pracují. Na příslušné vysoké škole se učí teorii daného problému a její aplikaci a současně mají pracovní poměr na daném ministerstvu, kde „empiricky zakouši““ to, co se učí na vysoké škole. Jaký je efekt zmíněného „modelu“? Dvojí a rozporný.

$\mathrm{Na}$ jedné straně se studenti nevěnují plně studiu, jak by si vysokoškolští pedagogové představovali. Na straně druhé ale student získává praxi, a zároveň si ho dané ministerstvo „otestuje“. Osvědčí-li se (neschopného studenta by ministerstvo, na rozdíl od řádného pracovníka, ani nezaměstnávalo), stává se relativně snadno po skončení školy řádným zaměstnancem ministerstva.

V př́padě Ministerstva obrany je taková praxe nemožná. Student denního studia studující na vojenské škole nemůže být současně zaměstnán jako ministerský úředník. Nemá tedy možnost získávat obdobné zkušenosti jako zmínění civilní studenti. Pro takového (,praxí státní správy netknutého“) absolventa vojenské školy je ve většině př́ípadů problematické se ucházet o určité místo na Ministerstvu obrany, protože nemá potřebné zkušenosti. Samožrejmě že jsou i určité koncepční a analytické činnosti, které může připravený absolvent vysoké školy v rezortu Ministerstva obrany zvládat, aniž by k tomu 
potřeboval vojenskou praxi. Jestliže se však jedná o „vojenské činnosti“, pak k tvorbě analýz a koncepcí jsou žádoucí zkušenosti z vojenské praxe.

Vznikají tak otázky, na něž by měli hledat odpovědi řídící pracovníci Ministerstva obrany: Je soudobý systém kariérního postup nastaven optimálně? Nebrání mladým talentovaným absolventům v uplatnění pro oblast analytické činnosti? Je daný věk přiměřený s ohledem na zvláštnosti analytických a koncepčních činností, které se týkají vojenské problematiky? Pokud není zjištěná výše věku přiměřená, jaké cesty se nabízejí ke změně daného stavu?

Jestliže se necháme inspirovat praxí „mladých ministerstev“, která nabírají zmíněné absolventy vysokých škol, pak se vtírá otázka, jakým zpo̊sobem zakomponovat do studia na vojenských školách praxi na různých postech v rezortu Ministerstva obrany? Zcela jistě (nebo téměř jistě) ne způsobem, kdy daný student by tzv. stážoval určitou dobu na ministerstvu. Z praxe takových stáží mám poznatky, že tito studenti nejsou př́liš motivovaní k výkonu, a zároveň spíše ,překážejí “ v práci, protože nemají bezprostředně žádnou odpovědnost. Zároveň se ani nedostávají do bezprostředních situací, které musí řšit, poněvadž je s výkonem dané činnosti nespojuje pracovní poměr, a některé informace potřebné pro řešení problému ani objektivně neumí získat.

Můžeme si však postavit otázku: Je možné najít jiný účinný způsob, jak zakomponovat dlouhodobou praxi do studijních programů vojenských škol, aby tato měla podobné účinky jako ministerská (zaměstnanecká) praxe oné skupiny civilních vysokoškolských studentů, po nichž je ze strany příslušných ministerstev vysoká poptávka?

To je otázka, na níž mohou pomoci řídícím orgánům Ministerstva obrany hledat odpověd' vojenské školy. K tomu, aby vojenské školy mohly patřičně zareagovat změnou obsahu učebních programů, jsou potřebné informace o uplatnění absolventů vojenských škol v praxi. Má rezort Ministerstva obrany takové informace k dispozici? Byl prováděn výzkum o uplatnění absolventů v praxi? Poskytuje Ministerstvo obrany svým školám informaci v podobě požadavku na profil absolventa školy v oblasti vědomostí, dovedností a schopností? Pokud ano, je na vojenských školách, aby tuto poptávku ,,přetavily“ do obsahu učebních programů. Jestliže školy takovou informaci nemají, budou pravděpodobně spíše učit to, co samy považují za důležité, přestože ve skutečnosti to nemusí být důležité. $V$ tom př́ípadě to však není chyba školy (nebo jen chyba školy), že učí to, co praxe nepoptává. Je to chyba v systému ř́zení rezortu, který nedefinuje poptávku svého personálu po vzdělání.

Druhá skupina problémů se týká oblasti pracovních zkušeností. V celé zkoumané skupině převažují zkušenosti z veřejného a komerčního sektoru, které se pohybují v intervalu 40-50 \%. V komerčním sektoru pracovali před prŕíchodem na ministerstvo nejvíce pracovníci Ministerstva financí a Ministerstva spravedlnosti. Pracovníci Ministerstva obrany mají (vcelku očekávaně) nejmenší pracovní zkušenosti z komerčního sektoru. V ostatních ukazatelích předchozích pracovních zkušeností se Ministerstvo obrany od jiných ministerstev príliš neliší.

Z hlediska počtu odpracovaných let ve své stávající funkci padá mýtus o představě, že pracovníci ministerstev se dlouho drží ve svých funkcích. Přibližně toliko polovina ze všech dotázaných zaměstnanců ministerstev pracovala ve své funkci déle nežli tři roky. V případě Ministerstva obrany činí tento podíl $60 \%$ dotazovaných. Na rozdíl od Ministerstva obrany velká část zaměstnanců jiných ministerstev pracuje ve své funkci poměrně dlouho (11 a více let). Ministerstvo obrany má poměrně vyvážené zastoupení 
v počtu jednotlivých sledovaných let odpracovaných ve stávající funkci. Nevyváženost jiných ministerstev je dána pravděpodobně negativním dopadem neúčinnosti zákona o státních zaměstnancích a v př́ípadě Ministerstva obrany pravděpodobně relativně propracovaným kariérním postupem.

Na straně druhé se ukazuje, že cca $70 \%$ dotazovaných pracuje ve veřejné správě více jak pět let. Pokud vezmeme počet odpracovaných let jako indikátor zkušenosti z práce ve veřejné správě, pak dotazovaná skupina zaměstnanců Ministerstva obrany má nejdelší zkušenosti z této práce. Přes $53 \%$ dotazovaných zaměstnanců pracuje ve veřejné správě 21 a více let. To je vysoko nad průměrem 21 let všech ministerstev. Jestli mám na tuto skutečnost reagovat v duchu oponentských připomínek, pak otázka zní: je to tak dobře? Odpovědět na tuto otázku není jednoduché. Na jedné straně může dané číslo vypovídat o nakumulované zkušenosti, na straně druhé vypovídá o již zmiňovaném vysokém věkovém průměru. Seriózní odpověd' na danou otázku mohou dát jen samotní „vnitřní znalci“" existujícího systému.

Z pohledu vnímání své vlastní role na ministerstvu z pozice zaměstnance a z hlediska řešení pracovních úkolů je zajímavé sledovat, jak samotní zaměstnanci vnímají svoji roli. Z hlediska své pozice analytických a koncepčních pracovníků bychom pravděpodobně očekávali, že také takto budou svoji roli označovat. Ve skutečnosti tomu tak zdaleka není. Termínem „úředník“ označuje svoji roli přibližně polovina dotazovaných, přičemž úředníkem se rozumí osoba, která vykonává určité administrativní činnosti a činí tak bezprostředně na pokyny nadřízeného či podle jasně stanovených pravidel a postupů.

V prŕpadě Ministerstva obrany tak tuto roli označuje pouze $30 \%$ dotazovaných. Podobně tuto roli označují analytičtí a koncepční pracovníci Ministerstva financí. Pracovníci Ministerstva obrany také nadprůměrně (23\%) označují svoji činnost termínem „manažer“. Z hlediska specifiky zkoumané skupiny by mělo spíše platit, že se př́islušní respondenti označí jiným termínem nežli ,úředník“. Pokud chceme z uvedeného vyvozovat nějaké závěry, zda je chápání uvedené role „úředníka“ pozitivní či negativní, je potřebné hledat na danou otázku odpověd' v kontextu chápaní složitosti a řešení problémů.

Výzkum ukázal, že téměř polovina dotazovaných uvedla, že problémům, které mají jediné, jasné a relativně jednoduché řešení, se věnují denně. Na Ministerstvu obrany takto tyto problémy označilo $44 \%$ dotazovaných Oproti tomu s problémy, jejichž řešení si vyžaduje tvořivý př́istup, protože nemají jasné a jednoduché řešení, se denně setkává přibližně čtvrtina dotazovaných. Situace je poměrně stejná na všech ministerstvech. Podle mého soudu jde o „nezdravý“ jev. Analytičtí a koncepční pracovníci by měli primárně řšit takové problémy, které odpovídají jejich vysoké kvalifikaci a erudici. Pokud tomu tak není, je to prríklad neefektivního a neúčelně použitého personálu, resp. neracionálně použitých zdrojů. Je to problém, jímž by se měla zabývat vláda (resp. jednotliví ministři). Na straně druhé je potřebné říci, že přibližně třetina dotazovaných uvádí, že se takovými složitými úkoly zabývají několikrát za týden. Tuto informaci si lze ale vyložit i z jiného úhlu. Jestliže se daní pracovníci musí zabývat řešením „každodenních“ (spíše rutinních) úkolů, nemá tato časová zátěž dopad na kvalitu a efektivnost řešení složitých úkolů? Není zde jedna z cest, jak dosahovat úspory ve státní správě (Ochrana a Půček, 2012)?

Varující poznatky byly zjištěny při prověřování četnosti činností zkoumané skupiny pracovníků, které byly komparovány jako tzv. hašení požárů versus strategické činnosti. 
Negativním je zjištění, že téměř desetina dotazovaných uvedla, že tzv. hašení požárů, jímž se rozumí okamžité, nenadále a neočekávaně se objevivší operativní činnosti, na které je nutno ad hoc okamžitě zareagovat, zabírá této skupině zaměstnanců více jako polovinu pracovní doby! Další třetina uvádí, že tato doba na hašení požárů činí pětinu až polovinu pracovní doby! To je negativní zjištění, které je potřebné řešit, protože kapacita vysoce kvalifikovaných analytických a koncepčních pracovníků je podstatnou měrou vyčerpávána jinými činnostmi, nežli jsou strategické činnosti s dlouhodobým zaměřením. Z ekonomického hlediska jde o prŕípad neefektivního a neúčelného nakládání se zdroji a ekonomicky neracionální využití personálu. Navíc taková činnost způsobuje i další škody, k nimž patří například ztráta motivace $\mathrm{k}$ výkonu. Příčiny tohoto stavu mohou být různé a je potřebné je podrobně prozkoumat odpovědnými řídícími orgány a přijmout účinná opatření ke změně existujícího stavu. Skutečnost, že pracovníci se v takové míře a v takové frekvenci zabývají „hašením“ požárů může např́klad znamenat, že existují chyby v systémovém řízení, či se daná skupina pracovníků dostává $\mathrm{k}$ řešení úkolů teprve tehdy, když se situace stává krizovou a řešení prrípadů urgentní. Je to problém, jímž by se mělo zabývat vedení rezortů.

Výzkum ukazuje na další negativní jev. Jím je skutečnost, že ani jedno z ministerstev nemá dostatečné kapacity pro dlouhodobé plánování a strategické činnosti s více než ročním horizontem. Také tento stav je možné označit jako alarmující, protože největší část své pracovní doby (mezi jednou čtvrtinou až jednou polovinou) se zkoumaní pracovníci věnují tzv. operativním činnostem. Na Ministerstvu obrany se pouhá $4 \%$ (!) pracovníků mohou věnovat strategickým činnostem více jak polovinu pracovní doby. Situace na ostatních ministerstvech je obdobná, protože průměrná délka pracovní doby, kterou zkoumaná skupina pracovníků věnuje strategickým činnostem, činí taktéž pouhá $4 \%$. To je typický př́ípad ekonomicky neúčelného použití zdrojů, kdy vysoce kvalifikovaní pracovníci, kteří mají navázaný pracovní poměr právě na výkon koncepční, analytické, strategické a řídící činnosti, tuto mohou vykonávat jen v omezené míře. Je to asi tak, jako když si pořídíme špičkovou výpočetní techniku s odpovídajícím vysoce kvalifikovaným servisem, a nakonec ji budeme používat jen jako psací stroj. Daná situace si žádá řešení. Je totiž dále neúnosné, jak uvádí přes osmdesát procent respondenti̊, že strategickým činnostem se věnují pouze jedno procento až jednu pětinu své pracovní doby. Situace je obdobná na všech ministerstvech. Protože se daný problém týká všech ministerstev, mělo by řešení tohoto problému být jedním z reformních úkolů vlády. Pokud se existující stav nepodaří změnit, zůstanou jakékoliv reformní kroky státní správy pouze neuskutečnitelným přáním.

Problém spokojenosti respondentů byl zkoumán z různých pohledů. Výzkum ukázal, že pokud jde o jistotu zaměstnání, na Ministerstvu obrany $69 \%$ dotazovaných volilo odpovědi „rozhodně spokojeno“, resp. „spíše spokojeno“. Rozhodně nespokojených jsou pouze $4 \%$ dotazovaných. Zjištěný stav přibližně odpovídá stavu na dalších ministerstvech. Na straně druhé je potř̌ebné říci, že téměř pětina dotazovaných není ani nespokojena a ani spokojena. Připočteme-li k této skupině indiferentních respondentů nespokojené zaměstnance, pak Ministerstvo obrany může hledat způsoby, jak motivovat téměř jednu třetinu dotazovaných zaměstnanců. Protože celková situace je i na jiných ministerstvech obdobná, mělo by exekutivní orgány zajímat, jak zvýšit motivaci zmíněné skupiny pracovníků. Jednou z významných cest se může stát přijetí účinného zákona o službě státních zaměstnanců. Jím lze nepochybně podstatnou měrou řešit problém vnímané vyšší jistoty zaměstnání. 
Z hlediska zajímavosti práce vyjádřili respondenti Ministerstva obrany rozhodnou spokojenost ve $45 \%$ př́padů a $42 \%$ dotazovaných je spíše spokojených. To je mírně nadprůměrný stav ve srovnání s jinými ministerstvy. Pro Ministerstvo obrany je toto zjištění významným sociálním kapitálem, kdy je zřejmé, že rezort Ministerstva obrany má dotyčné skupině zaměstnanců z hlediska zajímavosti práce co nabídnout.

Taktéž v oblasti spokojenosti s délkou pracovní doby je Ministerstvo obrany nad průměrem ostatních ministerstev. Rozhodnou spokojenost a spíše spokojenost vyjadřuje $86 \%$ dotazovaných, tedy o celou desetinu více, nežli je průměr za všechna ministerstva.

Velká část dotazovaných vyjádřila spokojenost i s organizací pracovní doby. Také v tomto př́padě je Ministerstvo obrany nad průměrem. Devadesát procent dotazovaných vyjadřuje rozhodnou spokojenost a spíše spokojenost v srovnání s průměrnou odpovědí za všechna ministerstva, kdy spokojenost vyjádřilo $78 \%$ dotazovaných. Z tohoto hlediska je Ministerstvo obrany bezproblémovým ministerstvem, nebot' pouhá $4 \%$ dotazovaných jsou spíše nespokojená a pouhé jedno procento dotazovaných vyjádřilo rozhodnou nespokojenost.

V oblasti hodnocení vztahů s přímými nadř́zenými byla zjištěna na všech ministerstvech vysoká spokojenost. Na Ministerstvu obrany každý druhý dotazovaný vyjádřil rozhodnou spokojenost. Spíše spokojených je $34 \%$ dotazovaných. To ve svém souhrnu odpovídá průměrné relativní spokojenosti všech ministerstev. Pouze $2 \%$ dotazovaných pracovníků Ministerstva obrany vyjadřují rozhodnou nespokojenost. Na straně druhé i v této oblasti je co zlepšovat. Každých patnáct dotazovaných ze sta totiž spokojenost nevyjadřuje.

Z hlediska možnosti povýšení panuje mezi ministerstvy největší spokojenost na Ministerstvu obrany. Rozhodně spokojených je $13 \%$ dotazovaných, spíše spokojených je $27 \%$. Žádné ze zkoumaných ministerstev nedosahuje takovou vysokou úroveň relativní spokojenosti $(40 \%)$, která v souhrnu za obě úrovně spokojenosti činí v průměru za všechna ministerstva $30 \%$. To je odraz dvou základních faktorů. Pozitivního faktoru relativně nejpropracovanějšího systému povyšování na Ministerstvu obrany ve srovnání s jinými ministerstvy. Na straně druhé se zde pravděpodobně projevuje negativní vliv neúčinnosti zákona o státních zaměstnancích. Proto také je celkem za ministerstva spíše nespokojených $16 \%$ dotazovaných, přičemž ani spokojených a ani nespokojených je $46 \%$ dotazovaných. A to je vysoké číslo. Podobný stav nalézáme na Ministerstvu obrany, kde ani spokojených a ani nespokojených je $41 \%$ dotazovaných a spíše nespokojených je $14 \%$ dotazovaných. To znamená, že na ministerstvech je každý druhý pracovník nemotivovaný (př́padně demotivovaný). To podle mého soudu ukazuje na velké rezervy v oblasti práce s personálem. Nemotivovaný personál je jistě méně výkonný a méně efektivní ve své činnosti. Taktéž nemotivovaný personál nebude pravděpodobně iniciativně a samostatně hledat netvůrčí řešení složitých úkolů. Opět se tak dostáváme k dalšímu možnému směru reformy státní správy v oblasti personální práce, kdy institucionálním předpokladem je účinný zákon o státní službě. Základní protiargument, že realizace zákona o státní službě je náročná z hlediska požadavkủ na zdroje, obstojí jen částečně, resp. v kontextu účetního a bilančního pohledu na rozpočet. Ano, z uvedeného pohledu je náročná na finanční zdroje. Avšak je potřebné dodat, že je náročná na zdroje v podmínkách, kdy není systémově reformován způsob rozpočtování a nakládání $\mathrm{s}$ veřejnými výdaji jako se vzácnými (tedy omezenými) zdroji, které je třeba ekonomicky 
co nejracionálněji použít. To se v soudobém systému odměňování pracovníků neděje. Všichni pracovníci jsou v podstatě ohodnocováni za svoji práci (či spíše časovou setrvalost ve veřejné správě) na stejném principu. Kdo déle setrvává, získává. Protože neexistuje výkonový systém financování a rozpočtování, v němž jsou pracovníci hodnoceni na principu výkonu a nikoliv ,časové výdrže“ ve veřejné správě, nepochybně dochází k promrhávání zdrojů. Platíme z veřejného rozpočtu i takové pracovníky, kteří přinášejí malý, žádný či dokonce záporný užitek. To je iracionálně nastavený systém. Současný systém neumí zřetelně diferencovat v odměňování za odvedenou práci, nebot' neexistují (vedle morálních, ideových) pohnutek) žádné dodatečné dostatečně silné materiální stimuly $\mathrm{k}$ výkonu, které by dovedly diferencovat přínos každého pracovníka za jeho uskutečněný výkon. Změna takového stavu není samozrejmě jednoduchá, protože předpokládá, aby i na nejvyšších řídících úrovních byli špičkoví odborníci. V této oblasti, je potřebné kriticky říci, že jsme se s rovnostářskou ideou předchozího režimu, který padl před čtvrtstoletím, v podstatě nevyrovnali. Nevadí to politickým elitám naší společnosti, či to snad některým i vyhovuje, že na řídících postech mohou být i neschopní?

V oblasti profesního rozvoje a platového ohodnocení výzkum ukázal, že je na všech ministerstvech rozhodně spokojeno $13 \%$ pracovníků. V př́padě Ministerstva obrany je to $12 \%$ dotazovaných. Celkem je relativně spokojena přibližně polovina dotazovaných, a to jak na Ministerstvu obrany tak i celkově za ministerstva. Indiferentní (ani spokojena a ani nespokojena) je přibližně čtvrtina dotazovaných. Jestliže k tomu v prrípadě Ministerstva obrany (a stejně tak i za ministerstva celkem) připočteme pětinu spíše nespokojených a nespokojených dotazovaných, vidíme že v oblasti profesního rozvoje je dosti prostoru pro zlepšování personální práce. Jedná se obdobný problém nemotivovaného či demotivovaného personálu, jak již bylo výše zmiňováno.

Řešení problému souvisí i dílem s platovým ohodnocením pracovníků Na Ministerstvu obrany a stejně tak i obdobně na jiných ministerstvech je polovina dotazovaných relativně spokojených s platovým ohodnocením, avšak čtvrtina pracovníků je nespokojena. To je relativně velký počet nespokojených (a pravděpodobně i nemotivovaných a demotivovaných) pracovníků, který by měl vést řídící orgány k přjietí takových opatření, které by vedlo k nápravě stavu. Rešení spočívá v již zmiňovaných systémových změnách financování (výkonovém rozpočtování) státní správy se současným přijetím účinnosti zákona o státních zaměstnancích.

Pokud budeme provádět celkové srovnávání jednotlivých ministerstev z hlediska jednotlivých aspektů spokojenosti, zjistíme, že mezi jednotlivými ministerstvy nejsou velké rozdíly. To však neznamená, že není co zlepšovat. Naopak jsem toho názoru, že ,přibližná stejnost“" zjištěného stavu vypovídá spíše o tom, že všechna ministerstva se potýkají se stejnými problémy, které vyžadují systémová řešení ze strany vrcholových funkcionářo̊ rezortů a politických elit. Zbývá zmínit, že systémová řešení mohou prosadit jen špičkoví řídící pracovníci. Jsou takoví pracovníci vždy a všude na př́slušných postech?

V oblasti podmínek práce se výzkum soustředil na dotazování o disponibilních znalostech a dovednostostech pro zvládnutí úkolů a na prověřování faktoru času. V této oblasti se ministerstva mezi sebou nijak výrazně neliší. Přes $90 \%$ dotazovaných uvádí, že má dostatek znalostí pro zvládání úkolů. To znamená, že daní pracovníci se považují za dostatečně kompetentní ke zvládání úkolů, kdy nemají pocit, že by jim byly zadávány úkoly nad jejich schopnosti. Negativním zjištěním však je, že pouze $60 \%$ dotazovaných 
(v př́ípadě Ministerstva obrany $56 \%$ ) uvádí, že má dostatek času pro kvalitní výkon své práce. Čtvrtina dotazovaných pracovníků Ministerstva obrany pocit’uje nedostatek času pro kvalitní výkon práce. A to je zajisté důvod, proč daný stav změnit, protože samotní respondenti tento časový deficit pojímají jako faktor nekvalitního výstupu jejich práce. Jestliže si tuto úvahu promítneme do praxe, pak výstupem jsou nekvalitní relevantní dokumenty. Pokud se stávají tyto nekvalitně vypracované dokumenty nástroji pro ř́zení rezortu, pak podávají neúplnou či deformovanou informaci pro rozhodovací činnost. V druhém př́padě, jestliže jsou tyto „,chvatně vypracované“ dokumenty připomínkovány a následně patřičně přepracovány, vznikají tak dodatečné náklady na jejich kvalitní dopracování, přičemž tato dodatečná činnost zároveň indukuje další časový deficit, který vznikl neplánovaně s daným dodatečným přepracováváním dokumentů.

Tato indikovaná situace ukazuje na defekty v řídící práci rezortů, kterou je žádoucí systémově změnit tak, aby byly eliminovány rušivé vlivy produkující následné „hašení požárů‘. Ukazuje se totiž, že téměř tři čtvrtiny respondentů Ministerstva obrany uvádí, že má dostatek informací pro kvalitní výkon své práce. Pouze jedno procento vyjadřuje rozhodný nedostatek informací pro kvalitní práci. Zdá se tedy, že podstata problému pro kvalitní výkon práce spočívá v samotné organizaci a způsobu řízení rezortu, v tom že daný systém produkuje distorzní (rušivé) činnosti, které vedou k nekvalitní práci. Za kritickou zmínku stojí, že pouze $9 \%$ dotazovaných pracovníků Ministerstva obrany se vyjadřuje, že rozhodně má dostatek informací pro své rozhodování (resp. 58 \% uvádí odpověd' „spíše ano“), přičemž průměr za ministerstva činí 13\% (resp. 53 \% pro odpověd” „spíše ano“). Celá třetina dotazovaných na Ministerstvu (obdobně i celkově za ministerstva) má relativní nedostatek informací, resp. se nedovede rozhodnout, zdali jsou dané informace dostatečné či nikoliv.

Při prověřování, zda respondenti mají dostatek příležitostí k neustálému rozšiřování znalostí a dovedností bylo zjištěno, že respondenti Ministerstva obrany uvádí ve $12 \%$ odpovědí, že rozhodně mají dostatek příležitostí k neustálému rozšiřování znalostí a dovedností, přičemž nesouhlas vyjádřila pětina dotazovaných. To znamená, že tato skupina respondentů cítí nedostatky ve vzdělávacím či sebevzdělávacím systému rezortu. Jde pravděpodobně o obecnější jev, nebot' v celkovém průměru za ministerstva odpověd” „rozhodně ano“ zvolilo 14 \% respondentů a nesouhlas vyjádřila čtvrtina dotazovaných. Opět se jedná o problém, který by měly řešit odpovědné rezortní složky.

V oblasti pocitu vykonávané práce, hrdost na práci na ministerstvu a zkoumání doby setrvání v pracovním poměru u svého zaměstnavatele bylo zjištěno, že více jak tři čtvrtiny dotazovaných pracovníků Ministerstva obrany souhlasilo s výrokem, že mají pocit z užitečně vykonávané práce. Ministerstvo obrany se tak zařadilo nad průměr všech ministerstev, kdy s daným výrokem souhlasilo 70 \% dotazovaných. Přibližně desetina dotazovaných pracovníků ministerstev, stejně jako i pracovníci Ministerstva obrany vyjadřují nesouhlas se sdílením tohoto pocitu. Pokud k této skupině dotazovaných pracovníků Ministerstva obrany připočteme $15 \%$ těch, kteří jsou v odpovědi indiferentní, pak čtvrtina dotazovaných pracovníků Ministerstva obrany nesdílí pocit užitečnosti z vykonávané práce. To je relativně velké číslo, za nímž se může skrývat nižší (či nízká nebo chybějící) motivace ke kvalitní práci. V případě ministerstev jako celku je to téměř třetina dotazovaných. Proč tomu tak je, by mělo zajímat všechny ministry a celou exekutivu, protože lidé, kteří nemají pocit z užitečně vykonávané práce s velkou pravděpodobností nebudou hledat nové přístupy a tvořivá řešení problémů. 
S uvedeným problémem souvisí i pocit hrdosti na vykonávanou práci na ministerstvu. S pocitem hrdosti se na ministerstvech ztotožňuje přibližně polovina dotazovaných, avšak nesouhlas vyjadřuje desetina respondentů. Ministerstvo obrany se od ostatních ministerstev zjevně liší. Téměř tři čtvrtiny dotazovaných pracovníků Ministerstva obrany sdílí pocit hrdosti na svoji práci a pouze $5 \%$ dotazovaných vyjádřilo nesouhlas. Pokud však vezmeme na zřetel i indiferentní odpovědi (v př́padě Ministerstva obrany je to $23 \%$, resp. $31 \%$ pro ministerstva jako celek, je zřejmé, že na ministerstvech najdeme dostatek personálu, který se z různých důvodů motivačně neztotožňuje se svojí prací na ministerstvu. Lze tuto skupinu pracovníků motivovat ke své práci tak, aby pocit'ovala hrdost? To je otázka, na kterou by měly hledat odpověd' rídící orgány ministerstev. Nebo je to spíše sysifovské úsilí najít pro část těchto pracovníků motivaci k práci a je lépe místo nich hledat jiné (motivovanější a výkonnější) pracovníky? Pokud je druhá odpověd' faktická, pak jedním z nástrojů k jejímu řešení je i přijetí zákona o státních zaměstnancích.

V oblasti vzdělávání bylo prověřováno, jakých vzdělávacích kurzů se respondenti zúčastnili. Byly zkoumány tyto kurzy: oblast politik EU, manažerské dovednosti, strategické řízení, komunikace, metody analýzy a tvorby politik, vedení lidí, hodnocení programů a politik. Vzhledem ke specifice činností Ministerstva obrany nepřekvapí, že pouze $20 \%$ respondentů se zúčastnilo vzdělávacích programů v oblasti politik EU. Je to nejméně ze všech ministerstev, kdy průměr za všechna ministerstva je $35 \%$. Co se týče manažerských dovedností, je Ministerstvo obrany s 36\% těsně nad průměrem. Je to málo či dosti? Podle mého soudu by téměř všichni pracovníci zkoumané skupiny měli mít absolvovaný kurz „manažerské dovednosti“, kam při prověřování tohoto problému byl např́klad řazeny projektový management, řízení lidských zdrojů. To je problematika, kterou musí daná skupina pracovníků řešit. Řídící pracovníci rezortu se mohou dopátrat, zda daný stav spíše odpovídá mému názoru, nebo naopak to znamená, že systém př́ípravy na vysokých vojenských školách je natolik účinný, že nebylo potřebné dále tuto skupinu pracovníků vzdělávat.

Jiná situace je v oblasti vzdělávání nazvaném „strategické řizení“. Zde Ministerstvo obrany dominuje. Celkem $35 \%$ respondentů uvádí, že se takto zaměřeného školení zúčastnilo. Je to více jak dvojnásobně vyšší účast ve srovnání s průměrem všech ministerstev. Rezervy lze spatřovat v oblasti školení „,metody analýz“. Pouze jedenáct pracovníků ze sta absolvovalo takový druh školení. A to je zcela jistě málo za předpokladu, že se s těmito metodami podrobně neseznamují studenti vysokých vojenských škol. Tvořivé osvojení si těchto metod je nepochybně jedním z předpokladů, jak provádět hodnotné analýzy a formulovat odpovídající doporučení. Je to ale problém všech ministerstev, protože v průměru pouze $10 \%$ dotazovaných odpovědělo, že takové školení absolvovalo. Na straně druhé je potřebné říci, že 61 \% respondentů Ministerstva obrany uvedlo, že absolvovali tzv. jiný druh školení. To je relativně uspokojivý, mírně nadprůměrný stav. Problémem samozřejmě je, že výzkum nezachycoval účinnost poskytovaných vzdělávacích programů. Co je však možné říci, že respondenti Ministerstva obrany poměrně silně poptávají další vzdělávání. Absolvování nějaké formy dalšího vzdělávání (jako jsou seminář, školení, kurzy) by přivítalo 80 \% dotazovaných. Poptávka po nových informacích je zejména u této skupiny pracovníků pozitivním faktem. Je to výzva vůči personální složce rezortu, která by měla identifikovat strukturu a obsah poptávky po vzdělávání a iniciovat jeho realizaci, a to at' již formou školení vlastními silami tak i př́padně outsorcováním. 
Z výzkumu vyplývá i další významný problém, který se týká státní správy jako celku. Je jím existence jevu, který je znám jako tzv. politizace státní správy. Jde o jev, kdy pracovníci státní správy jsou nuceni v rozporu s veřejným zájmem ve své pracovní činnosti prosazovat dílčí (politické, čili stranické) zájmy vedení rezortu. Tento tlak pocit’uje přibližně třetina dotazovaných. Na Ministerstvu obrany na otázku, ,zda je jeho práce často ovlivněna politickými zájmy“, odpovědělo souhlasně $29 \%$ dotazovaných. Pracovníci Ministerstva obrany ve srovnání s jinými ministerstvy tento tlak pocit’ují výrazně méně, než činí průměr ( 55 \%) za všechna ministerstva. Zdá se však, že pro státní správu v ČR je charakteristická její politizace. A to je negativní jev, který by měl být řešen exekutivou. Ta by však sama nesměla být v osidlech ,vlastní politizace státní správy“.

Závěrem konstatuji, že předložené závěry se pokoušejí pojmenovat některé palčivé problémy. Ty je samozřjmě potřebné dále uvnitř rezortu diskutovat a hledat cesty k jejich řešení. Článek se o nastínění některých východisek pro řešení problémů pokouší. Je na znalém a informovaném čtenáři, aby oddělil př́padný omyl od reality. Co však považuji za nejdůležitější je, aby se řídící orgány Ministerstva obrany danými a s nimi souvisejícími problémy zabývaly a řešily je.

Tento článek je výstupem z výzkumného projektu Grantové agentury České republiky P 404/12/0725 „Analytici politiky v ústřední státni správě České republiky:praktiky, profesni hodnoty a identita ".

\section{Literatura:}

BAKVIS, H. Advising the executive: think tanks, consultants, political staff and kitchen cabinets. In P. Weller, H. Bakvis \& R. A. W. Rhodes (Eds). The Hollow Crown: Countervailing Trends in Core Executives. London: Macmillan, 1997.

HOWLETT, M. Policy analytical capacity and evidence based policy making: Lessons from Canada. Canadian Public Administration, 2009, 52(2), 153-175.

HOWLETT, M. - WELLSTEAD, A. M. Professional policy work in federal states: Institutional autonomy and Canadian policy analysis. Canadian Public Administration, 2012, 55(1), 53-68.

OCHRANA, F. Metodologie sociálnich věd. Praha: Karolinum, 2013.

OCHRANA, F. - PŮČEK, M. Dosahováni úspor a omezování plýtvání ve veřejném sektoru. Praha: Wolters Kluwer, 2012.

PERNICA, B. Profesionalizace ozbrojených sil, trendy, teorie a zkušenosti. Ministerstvo obrany, Praha, 2007.

VESELÝ, A. Policy advisory system in the Czech Republic: From state monopoly to hollowing out? Paper for XXII ${ }^{\text {nd }}$ World Congress of Political Science in Madrid. Panel: Policy Advice and Policy Work (I): System and Configurations Thereof. July 8-12, 2012.

WellsteAD, A. M. - STEDMAN, R. C. - HOWLETT, M. Policy Analytical Capacity in Changing Governance Contexts: A Structural Equation Model (SEM) Study of Contemporary Canadian Policy Work. Public Policy and Administration, 2011, 26(3), 353-373.

Zákon č. 2/1969 Sb., o zřízení ministerstev a jiných ústředních orgánů státní správy, ve znění pozdějších předpisů. 